\title{
Airborne observations of mineral dust over western Africa in the summer Monsoon season: spatial and vertical variability of physico-chemical and optical properties
}

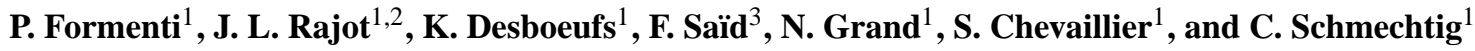 \\ ${ }^{1}$ LISA, CNRS, UMR7583 Université Paris Est Créteil et Université Paris Diderot Institut Pierre Simon Laplace, \\ Créteil, France \\ ${ }^{2}$ BIOEMCO, IRD, UMR211, Paris, France \\ ${ }^{3}$ Laboratoire d'Aérologie, Université de Toulouse/CNRS 5560, Toulouse, France
}

Received: 1 December 2010 - Published in Atmos. Chem. Phys. Discuss.: 24 January 2011

Revised: 6 June 2011 - Accepted: 22 June 2011 - Published: 6 July 2011

\begin{abstract}
We performed airborne measurements of aerosol particle concentration, composition, size distribution and optical properties over Western Africa in the corridor 2$17^{\circ} \mathrm{N}$ and $3-5^{\circ}$ E. Data were collected on board the French ATR-42 research aircraft in June-July 2006 as part of the African Monsoon Multidisciplinary Analysis (AMMA) intensive field phases in June-July 2006 using the AVIRAD airborne aerosol sampling system.

The aerosol vertical distribution was documented on an almost daily basis. In particular, the vertical distribution of mineral dust emitted locally by Mesoscale Convective Systems (MSC) was distinguished from that of mineral dust that was transported from the Saharan by the African Easterly Jet (AEJ). Mineral dust emitted in the Sahel by convectiondriven erosion was mostly confined in the boundary layer. One episode of injection of Sahelian mineral dust in the AEJ was observed. The elemental composition was found to be an element of difference between episodes, whereas the volume size distribution was more uniform.

For non-mixed dust, the single scattering albedo ranged between $0.88-0.93$ at $370 \mathrm{~nm}$ and between $0.91-0.99$ at $950 \mathrm{~nm}$, lower values being observed for Sahelian dust. In correspondence, the imaginary part of the complex refractive index varied between $0.002-0.004$ at $370 \mathrm{~nm}$ and between $0.001-0.002$ at $950 \mathrm{~nm}$.
\end{abstract}

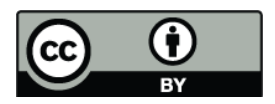

Correspondence to: P. Formenti (formenti@lisa.u-pec.fr)

\section{Introduction}

The role of mineral dust on climate change is prominent but still largely uncertain, as pointed out by the latest Intergovernmental Panel on Climate Change's report (Forster et al., 2007). Dust directly impacts the radiative budget by scattering and absorption of solar and infrared radiation, and by altering the microphysics and radiative properties of clouds and ice layers (DeMott et al., 2003; Koehler et al., 2009). Mineral dust also represents a significant input of nutrients (e.g., iron and phosphorous) to remote marine and terrestrial ecosystems (Jickells et al., 2005).

Africa is the world's largest source of mineral dust aerosols (Delmas et al., 2005; Laurent et al., 2008). Mineral dust steaming out of Africa towards the Atlantic ocean and the Mediterranean sea is emitted from various localized sources in the arid and semi-arid areas of the Sahara and Sahel, differing in intensity, seasonality and frequency (Goudie and Middleton, 2001; Prospero et al., 2002; Laurent et al., 2008). Because of their intensity and persistence throughout the year, up to very recently most of the research has focused in studying the emission and properties of dust emitted from arid areas in the Sahara (Pye, 1987; Sokolik et al., 2001; Laurent et al., 2008).

More recently, various authors have invoked the emission of mineral dust by wind erosion over the semi-arid areas of the Sahel in order to explain the summertime maximum in the aerosol load observed by satellites over Western Africa (Tegen and Fung, 1994; Yoshioka et al., 2005; Forster et al., 2007). The long-time record of horizontal visibility from meteorological stations (N'Tchayi et al., 1994; N'Tchayi

Published by Copernicus Publications on behalf of the European Geosciences Union. 
Mbourou et al., 1997; Goudie and Middleton, 2001) shows that the atmospheric content of mineral dust in the Sahelian part of western Africa is high and shows a very pronounced seasonal cycle despite high variability, both at the daily and inter-annual scales. This is largely explained by the alternance of two meteorological regimes. In boreal winter, the "Harmattan", a northeastern dry wind, is responsible for intense dust emissions in desert areas and very efficient transport towards the gulf of Guinea. At contrary, during summer, due to the northern displacement of the Inter Tropical Convergence Zone (ITCZ), the Sahel experiences, in the lower layers, the humid Monsoon flow from South-West. This shift induces a progressive organization of convection from isolated cells to large-scale propagating systems.

At the beginning of the rainy season, these systems, often not precipitating, are efficient in producing mineral dust by aeolian erosion over bare soils. As the Monsoon season progresses, the precipitation is enhanced inducing the scavenging of dust transported from remote sources and the local wind intensity is reduced. These phenomena prevent local aeolian erosion in the middle of the rainy season (Abdourhamane Touré et al., 2011).

The summertime column dust content over the Sahel results therefore from the superimposition of local emission and remote transport of dust emitted in the Sahara. Because these two large source areas have different mineralogy (Pye, 1987; Claquin et al., 1999; Caquineau et al., 2002), mixing or layering of dust transported from the Sahara and locally emitted by convection over the Sahel should be detectable through differences in the composition over the atmospheric column. Besides possible differences at the source due to different weathering, the different residence times should also result in different size distributions, locally emitted dust being in principle richer in coarse particles than long-range transported. The impact of transported and locally emitted dust is therefore expected to be different. In particular, differences in physico-chemical properties of Saharan and Sahelian mineral dust are expected to be evident in the optical properties of scattering and absorption, and should result in differences in the direct radiative impact.

In this paper, we present new data on the physico-chemical and optical properties that were acquired during twenty research flights over Western Africa between Niamey and Cotonou as part of the African Monsoon Multidisciplinary Analysis (AMMA) intensive field phases in June-July 2006. AMMA is an international project to improve our knowledge and understanding of the West African monsoon (WAM) and its variability with an emphasis on daily-to-interannual time scales (Redelsperger et al., 2006). It provided with a first time opportunity of performing observation of Sahelian mineral dust in a systematic way, that is, coupling ground-based, airborne, spaceborne observations and modeling.

The experimental strategy of the AMMA program was based on embedded multi-year, seasonal and intensive observation periods (Janicot et al., 2008; Lebel et al., 2010).
The summertime aircraft observations described in this paper were conducted from Niamey, in Niger, as part of the Special Observing Periods (SOPs) dedicated to the fine description of aerosols and convection. In particular, the present data were collected during the pre-monsoon and early-monsoon periods (called SOP1 and SOP2_a1, respectively), when summertime dust emissions from the Sahel are at their maximum. These observations are to be contrasted with those performed in wintertime during the so-called AMMA SOPO (AMMA SOP-0/DABEX when referred to the airborne component) period when local emissions do not occur and dust is purely transported from various sources in the Sahara (Haywood et al., 2008; Rajot et al., 2008; Osborne et al., 2008; Formenti et al., 2008).

Aircraft exploration of the atmospheric column up to $6 \mathrm{~km}$ was performed in the area between $13^{\circ}$ and $17^{\circ} \mathrm{N}$ to illustrate the vertical layering of the dust content under different emission and transport conditions. In addition, exploration of the area south of $13^{\circ} \mathrm{N}$ is also presented to illustrate the time evolution of the meridian extent of the dust transport region with the progression of the Monsoon season.

\section{Instrumentation}

Instruments have been operated onboard the Service des Avions Français Instruments pour la Recherche en Environnement (SAFIRE) ATR-42. With the necessary payload for AMMA, the aircraft had a maximum endurance of $4 \mathrm{~h}$. Minimum flight altitude is $300 \mathrm{~m}$ over land. Ceiling is approximately $7 \mathrm{~km}$. The aircraft was equipped with basic sensors for measuring the radiative, dynamic and thermodynamic properties of the atmosphere (Saiid et al., 2010).

Aerosol sampling was performed using the AVIRAD aerosol sampling system newly developed for AMMA. This system is described in detail in Formenti et al. (2011). It consists of an iso-axial and isokinetic inlet whose $50 \%$ passing efficiency has been estimated at $9 \mu \mathrm{m}$ in diameter. At the cruise speed of the ATR-42 $\left(93 \mathrm{~m} \mathrm{~s}^{-1}\right)$ the delivered volumetric flow rate is $3501 \mathrm{~min}^{-1}$.

This allows connecting the inlet to multiple instruments in parallel. Various straight sampling lines depart from the inlet to provide: (i) straight-levelled run 2-min averaged measurements of the particle absorption coefficient at 370 , 470, 520, 590, 660, 880 and $950 \mathrm{~nm}$ (aethalometer model AE31, Magee Sci.); (ii) 1-s measurements of the particle scattering and backscattering coefficients at 450, 550 and $700 \mathrm{~nm}$ (nephelometer model 3596, TSI Inc.); (iii) 6-s resolution number size distribution between 0.3 and $20 \mu \mathrm{m}$ in diameter (optical particle counter model 1.108, GRIMM); and (iv) bulk aerosol composition and mass concentration by on-line filter sampling on polycarbonate membranes (Nuclepore, Whatman). 


\subsection{Aerosol particle chemical composition}

Bulk samples of aerosol particles were obtained by filtration onto 42-mm diameter polycarbonate membranes (nominal pore size $0.4 \mu \mathrm{m}$ Nuclepore, Whatman) on polyethylene supports. Samples were collected only during horizontal flight legs lasting not less than 20-30 min in order to guarantee sufficient loading of the filter samples. Immediately after each flight, the loaded filters were stored in Petri dishes.

Samples were analyzed by wavelength-dispersive X-ray fluorescence (WD-XRF). WD-XRF analyses have been performed using a PW-2404 spectrometer by Panalytical. Excitation X-rays are produced by a Coolidge tube $\left(\mathrm{I}_{\max }=125 \mathrm{~mA}, \mathrm{~V}_{\max }=60 \mathrm{kV}\right)$ with a Rh anode; primary Xray spectrum can be controlled by inserting filters (Al, at different thickness) between the anode and the sample. Each element was analyzed three times, with specific conditions (voltage, tube filter, collimator, analyzing crystal and detector), lasting 8 to $10 \mathrm{~s}$.

Data were collected for 9 elements $(\mathrm{Na}, \mathrm{Mg}, \mathrm{Al}, \mathrm{Si}, \mathrm{P}$, $\mathrm{K}, \mathrm{Ca}, \mathrm{Ti}, \mathrm{Fe}$ ) using SuperQ software. The elemental mass thickness $\left(\mu \mathrm{g} \mathrm{cm}^{-2}\right)$, that is, the analyzed elemental mass per unit surface, was obtained by comparing the filter yields with a sensitivity curve measured in the same geometry on a set of certified geo-standards (ANRT GS-N). These geostandards were crunched in order to reduce and homogenize the grain size. Then they were deposited at different concentrations $\left(<150 \mu \mathrm{g} \mathrm{cm}^{-2}\right)$ on Nuclepore filters. The visual inspection of the deposit by electron microscopy suggested that grains are generally smaller than $5 \mu \mathrm{m}$ diameter. The atmospheric elemental concentrations were finally calculated by multiplying the analyzed elemental mass thickness by the ratio between the analyzed and the collection surfaces of each sample (16 and $28 \mathrm{~mm}$, respectively). This was possible as the aerosol deposit on the filters was rather uniform. Finally, for the AMMA samples, the limit of quantification of the technique ranged between $3 \times 10^{-3}$ and $13 \times 10^{-3} \mu \mathrm{g} \mathrm{cm}-2$ depending on element.

In addition, the iron oxide content was determined with the adapted CBD-method developed by Lafon et al. (2004). The iron oxide content is defined as the fraction of iron which is not structural, i.e., occurring in the crystal lattice of silicates (Karickhoff and Bailey, 1973). There are two major iron oxides in mineral dust (hematite, $\mathrm{Fe}_{2} \mathrm{O}_{3}$, and goethite, $\mathrm{FeO} \cdot \mathrm{OH})$ and these are responsible for its light-absorption properties in the UV-visible (Sokolik and Toon, 1999; Alfaro et al., 2004; Lafon et al., 2006). This method is an adaptation for aerosol filters (with typical material mass less than $500 \mu \mathrm{g}$ ) of the classical method of Mehra and Jackson (1960) for soil analysis. The method uses the CBD reagent to dissolve iron oxides selectively via reduction.

\subsection{Aerosol particle size distribution}

The particle number size distribution between 0.3 and $20 \mu \mathrm{m}$ was measured on 15 size classes in diameter by a GRIMM optical particle counter (OPC; GRIMM Inc., model 1.108) operated at 6-s time resolution.

The instrument, described in Heim et al. (2008), has been factory-calibrated prior the field campaign using monodisperse polystyrene sphere latex (PSL) whose complex refractive index $\tilde{\mathrm{n}}$ is equal to $1.59-0 i$ at $780 \mathrm{~nm}$, the working wavelength of the GRIMM OPC. The sphere-equivalent optical diameters needs to be converted to sphere-equivalent geometric diameters by taking into account the refractive index of the aerosol under investigation (Liu and Daum, 2000; Collins et al., 2000). The complex refractive index was set to $1.53-0.002 i$, in the range of published values available in the literature (Osborne et al., 2008; Schladitz et al., 2009; Petzold et al., 2009; McConnell et al., 2010). Variations of both the real and the imaginary parts in the range indicated by those measurements $(1.53-1.56$ for the real part; $0.001-$ 0.003 for the imaginary part) have not proven significant in altering the correction factor to be applied to the calibration sphere-equivalent optical diameter values in comparison to the uncertainties in the estimation of the refractive index as well as on those due to Mie resonance oscillations of the calculated scattering intensities.

The GRIMM OPC integrates light scattering between $46^{\circ}$ and $133^{\circ}$. Because the interest of this paper is on integrated optical properties (scattering and absorption coefficients), for which non-sphericity corrections are not very relevant, in the absence of a good estimate of the particle shape distribution, corrections to the scattering intensities due to particle shape have been neglected.

Number concentrations for particles larger than $0.3 \mu \mathrm{m}$, were converted to standard temperature and pressure (STP) using $T=20^{\circ} \mathrm{C}$ and $P=1013.25 \mathrm{hPa}$.

\subsection{Aerosol particle scattering coefficients}

The particle volume scattering coefficients (dry state) were measured at 450, 550 and $700 \mathrm{~nm}$ wavelength using a threewavelength integrating nephelometer (model 3563, TSI Inc., St. Paul, Minnesota). The instrument was operated at a volumetric flow rate of $301 \mathrm{~min}^{-1}$ and data were acquired at 1 -s resolution. It was factory-calibrated and checked prior and after the campaign. The measured scattering coefficients have to be corrected for angular truncation and Lambertian non-idealities (Anderson et al., 1996). Truncation corrections are related to the restricted angular opening of the nephelometer sensing volume with respect to the ideal case (Anderson et al., 1996). Corrections were performed by Miecalculations using the measured size distributions corrected for the effect of the refractive index and the missing particle fraction in the accumulation mode. The real part of the refractive index was left unvaried with the wavelength 
(1.53), whereas the imaginary part was set to 0.003 at 450 and $550 \mathrm{~nm}$ and 0.002 at $700 \mathrm{~nm}$. Due to the dominance of the coarse super-micron mode, the correction factor to be applied the measured scattering coefficient ranged between 1.4 and 1.5. The relative errors on the measured scattering coefficients, due to gas calibration and photon-counting statistics, remained well within $5 \%$.

The scattering coefficients were converted to standard temperature and pressure (STP) using $T=20^{\circ} \mathrm{C}$ and $P=$ 1013.25 $\mathrm{hPa}$. In the following they are expressed in $\mathrm{Mm}^{-1}$ $\left(1 \mathrm{Mm}^{-1}=10^{-6} \mathrm{~m}^{-1}\right)$.

\subsection{Aerosol particle absorption coefficients}

A spectral aethalometer (Magee Sci., model AE31) was used to measure the particle absorption coefficient at 370, 470, 520, 590, 660, 880 and $950 \mathrm{~nm}$. The instrument measures the light attenuation through a particle-laden quartz filter spot compared to a portion of the same filter medium that is left unexposed to the air stream and that is used as a reference. Because of its operating principle, the instrument can be operated only on straight and levelled runs at constant altitude when the air flow through the filter is constant. On those occasions, the reading of the internal mass flow meter remained constant within $2 \%$. Data were acquired at 2-min resolution and the volumetric flow rate was set to $201 \mathrm{~min}^{-1}$. The use of the aethalometer on pressurised aircraft is commonly critized because the instrument is not fully leak-tight. Possible contamination from the cabin due to leaks in the air flow circuit was discarded based on a serious screen on the data acquired at low-concentration.

The spectral light attenuation measured by the aethalometer as a function of time was corrected to yield the aerosol absorption coefficient according to Weingartner et al. (2003) and Collaud Coen et al. (2010). The empirical correction factor by Weingartner et al. (2003) allows to take into account the effect of multiple scattering of the light beam at the filter fibres of the unloaded filter (C factor in Weingartner et al., 2003), and the "shadowing effect" of absorbing particles progressively masking the incoming light whilst accumulating on the filter (R(ATTN) in Weingartner et al. (2003). This second effect loses importance as the aerosol single scattering albedo increases. The Weingartner et al. (2003) correction scheme does not allow taking into account the miscounting of particle scattering as absorption, which we accounted for by applying the correction factor proposed by Collaud Coen et al. (2010). In this work we set the $C$ factor to $2.14( \pm 0.21)$. For the range of single scattering albedo values $(0.85-0.99$ between 370 and $950 \mathrm{~nm})$ expected for mineral dust in the area (Redmond et al., 2010), R(ATTN) varied between 1 (first measurement after the spot change, ATTN $=0$ ) and 0.84 (last measurement after the spot change, ATTN $=100$ ). Due to the little spectral dependence put into evidence by Weingartner et al. (2003), and in the absence of

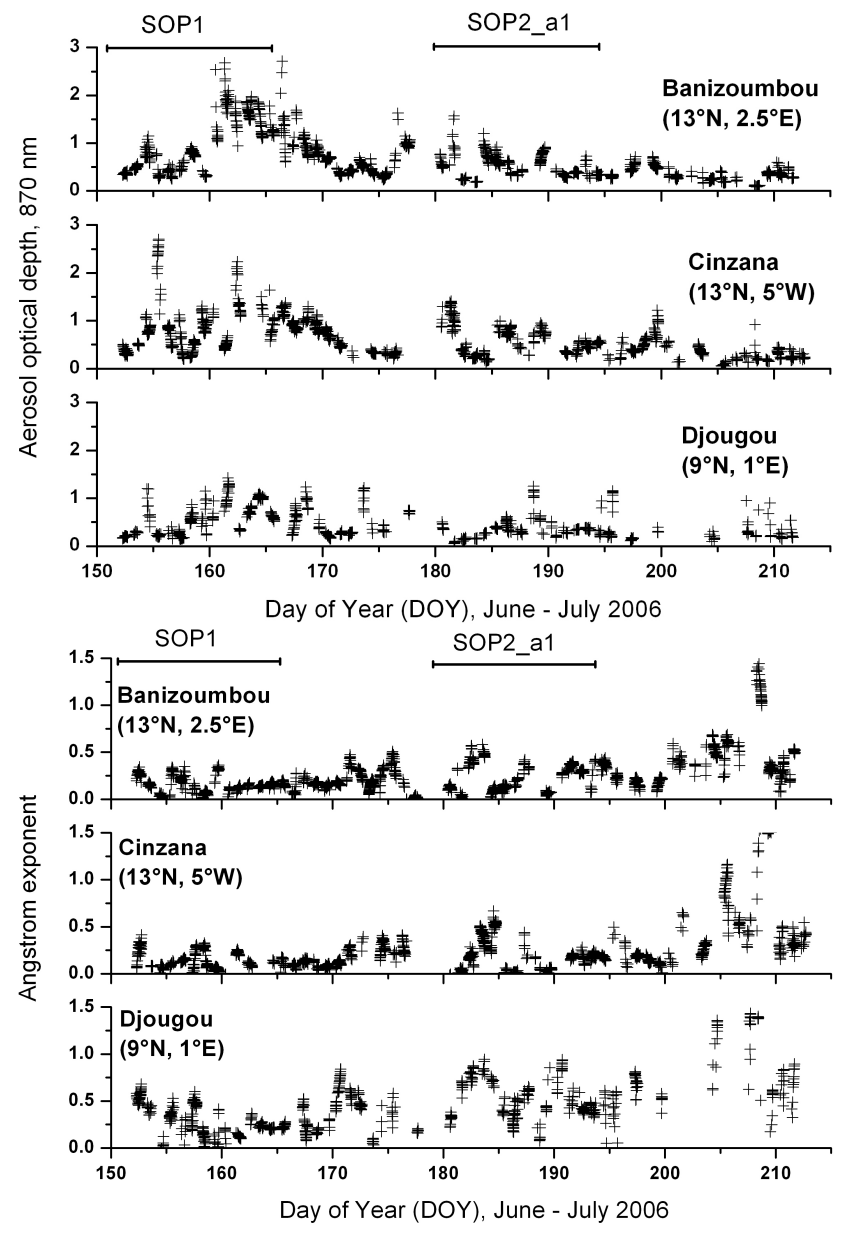

Fig. 1. Time series of aerosol optical depth (AOD) at $870 \mathrm{~nm}$ (upper panel) and the Angstrom exponent (lower panel) measured during June and July 2006 by the AERONET sunphotometers in Banizoumbou (Niger; $13^{\circ} \mathrm{N}, 2.5^{\circ} \mathrm{E}$ ), Cinzana (Mali; $13^{\circ} \mathrm{N}, 5^{\circ} \mathrm{W}$ ), and Djougou (Benin; $9^{\circ} \mathrm{N}, 1^{\circ} \mathrm{E}$ ).

further information, we considered the R(ATTN) values as independent of the wavelength.

Due to the dominance of scattering over absorption in mineral dust, the experimental uncertainty on the absorption coefficient is dominated by the term representing the miscounting of particle scattering as absorption. A formal error propagation analysis indicates that the relative error on the absorption coefficient varied in the range $13 \%-15 \%$ at $370 \mathrm{~nm}$ and $14-100 \%$ at $950 \mathrm{~nm}$ depending on the relative proportions of scattering over attenuation observed during the campaign.

As the scattering coefficients, the absorption coefficients were converted to standard temperature and pressure (STP) and are expressed in $\mathrm{Mm}^{-1}$. 
Table 1. Summary of information (date, location, aim) of the ATR-42 flights performed during the AMMA SOP1 and SOP2 a1 field phases. The corresponding Intensive Observational Periods (IOPs) are indicated.

\begin{tabular}{lllll}
\hline Flight ID & Date & Location & Objective & IOP \\
\hline V017 & $05 / 06 / 2006$ & Local over Banizoumbou & Atmospheric vertical structure & 1.1 \\
V018 & $06 / 06 / 2006$ & Local over Banizoumbou & Atmospheric vertical structure & 1.1 \\
V019 & $07 / 06 / 2006$ & North of Niger towards Algeria & Transition Monsoon/Harmattan & 1.1 \\
V020 & $08 / 06 / 2006$ & Local over Banizoumbou & Dust vertical structure & 1.2 \\
V021 & $11 / 06 / 2006$ & Local over Banizoumbou & Atmospheric vertical structure & 1.1 \\
V022 & $12 / 06 / 2006$ & Local over Banizoumbou & Atmospheric vertical structure & 1.1 \\
V023 & $13 / 06 / 2006$ & Niamey-Cotonou & Regional variability of the monsoon flux & 1.3 \\
V024 & $14 / 06 / 2006$ & Over sea, Guinea gulf & Regional variability of the monsoon flux & 1.3 \\
V025 & $14 / 06 / 2006$ & Cotonou-Niamey & Regional variability of the monsoon flux & 1.3 \\
V026 & $15 / 06 / 2006$ & Local over Banizoumbou & Atmospheric vertical structure & 1.1 \\
V027 & $01 / 07 / 2006$ & Local over Banizoumbou & Atmospheric vertical structure & 1.1 \\
V028 & $02 / 07 / 2006$ & Local over Banizoumbou & Atmospheric vertical structure & 1.1 \\
V029 & $03 / 07 / 2006$ & Niamey-Cotonou & Regional variability of the monsoon flux & 1.3 \\
V030 & $04 / 07 / 2006$ & Over sea, Guinea gulf & Regional variability of the monsoon flux & 1.3 \\
V031 & $04 / 07 / 2006$ & Cotonou-Niamey & Regional variability of the monsoon flux & 1.3 \\
V032 & $06 / 07 / 2006$ & North of Niger towards Algeria & Transition Monsoon/Harmattan & 1.1 \\
V033 & $07 / 07 / 2006$ & Local over Banizoumbou & Dust vertical structure & $1.2 / 2.0$ \\
V034 & $10 / 07 / 2006$ & Local over Banizoumbou & Atmospheric vertical structure & $1.1 / 2.0$ \\
V035 & $12 / 07 / 2006$ & Local over Banizoumbou & Atmospheric vertical structure & $1.1 / 2.0$ \\
V036 & $13 / 07 / 2006$ & Local over Banizoumbou & Atmospheric vertical structure & $1.1 / 2.0$ \\
\hline
\end{tabular}

\section{Area and period of study}

The large and regional scale features of the early Monsoon season in 2006 over western Africa are discussed by Janicot et al. (2008). Their analysis shows that the 2006 season was nearly-average but characterised by a later onset of the Monsoon (about 10 days) than expected from climatology. From June to July, the Intertropical Convergence Discontinuity (ITD) at the surface between the Monsoon wind and the Harmattan wind, moved from about $15^{\circ} \mathrm{N}$ to about $20^{\circ} \mathrm{N}$ (Janicot et al., 2008; Lothon et al., 2008). This resulted in an increase influence of moist air transported in the southwesterly Monsoon flow over the study area.

With respect to the dust content and origin, the analysis of satellite images, ground-based and airborne observations indicated that during SOP1 and SOP2_a1 mineral dust dominated the aerosol content north of $10^{\circ} \mathrm{N}$. This is shown by the time series of aerosol optical depth (AOD) at $870 \mathrm{~nm}$ and the Angstrom exponent (Fig. 1) measured by the sunphotometers of the Aerosol Robotic Network (AERONET) (Holben et al., 1998, 2001) located in the area.

Three stations located in the proximity of the area of observation had a significant number of observations: Banizoumbou (Niger; $\left.13^{\circ} \mathrm{N}, 2.5^{\circ} \mathrm{E}\right)$, Cinzana (Mali; $13^{\circ} \mathrm{N}, 5^{\circ} \mathrm{W}$ ), and Djougou (Benin; $9^{\circ} \mathrm{N}, 1^{\circ} \mathrm{E}$ ). Banizoumbou and Cinzana are located in semi-arid areas where mineral dust dominates, whereas Djougou represents vegetated areas mostly under the influence of the Monsoon flow. These characteristics are reflected in the sunphotometer data showing higher
AOD values and lower Angstrom exponent values in the two dust-dominated stations.

Dust in the Banizoumbou area was either produced by local erosion (by convective systems or Monsoon flow (Sow et al., 2009) or transported. Convective systems were either isolated cells of very local origin or large-scale organised systems, most of the time originating in the Air Mountains and on the Jos plateau (Janicot et al., 2008). During the flying periods, sixteen erosion events were detected in Banizoumbou on the basis of the record of the grain saltation, that is, of the horizontal movement of the dust grain induced by increased wind speed which was monitored with a saltiphone in the saltation layer, just above the soil surface (Spaan and van den Abeele, 1991). These corresponded to isolated cells or more organised convective systems, fifteen of which were followed by heavy rain (Desboeufs et al., 2010). These events mostly occurred in the late afternoon or at night and produced very high dust concentrations measured at the ground level (Marticorena et al., 2010). That is why the increase of AOD due to local dust emission does not really show up in the level 2.0 AERONET daytime series. Furthermore, the latter tends to be biased to lower values since events characterised by extremely high concentrations and associated with clouds are discarded.

Transported dust originated from the Sahara, from sources north east of Niger, mostly the Airr/Teneré, Tibesti/Ennedi corridor, and the Darfour areas (Kalu, 1979; Goudie and Middleton, 2001; Prospero et al., 2002). In summertime 


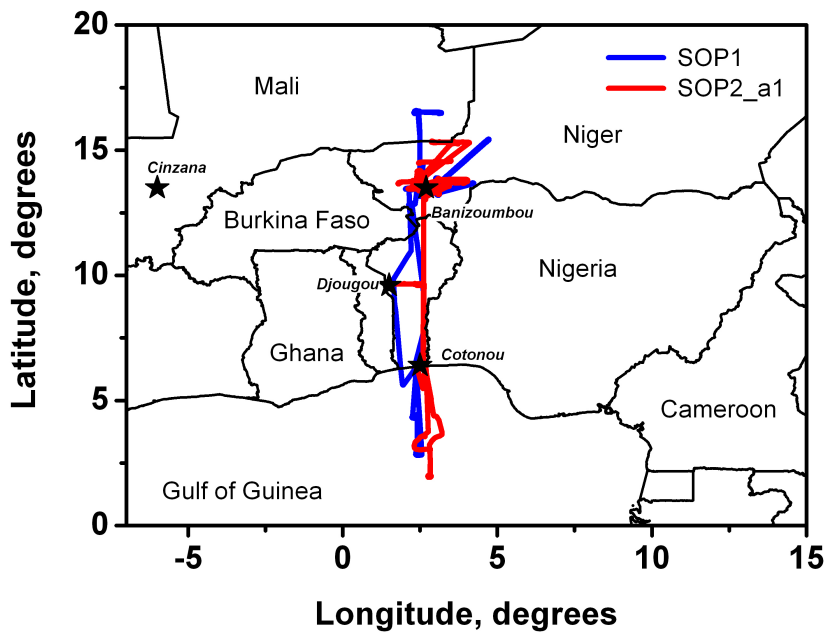

Fig. 2. The operating region of the ATR-42 during the AMMA SOP1 (1-15 June) and SOP2_a1 (1-15 July 2006) intensive phases. The aircraft was based in Niamey $\left(13^{\circ} \mathrm{N}, 2^{\circ} \mathrm{E}\right)$, the capital city of Niger.

easterly transport occurs above $1.5 \mathrm{~km}$ in the Saharan Air Layer (SAL) (Carlson and Prospero, 1972) through the African Easterly Jet (AEJ) that blows over $1.5 \mathrm{~km}$ and is strongest at around $4.5 \mathrm{~km}$ at the latitude of Niamey (Kalapureddy et al., 2010). This contrasts with the surface transport pattern occurring during wintertime (Kalu, 1979; Chiapello et al., 1995; Osborne et al., 2008; Heese and Wiegner, 2008; Kim et al., 2009; Léon et al., 2009).

The operating region of the ATR-42 during the AMMA SOP1 (1-15 June) and SOP2_a1 (1-15 July 2006) intensive phases are shown in Fig. 2.

The aircraft, based in Niamey $\left(13^{\circ} \mathrm{N}, 2^{\circ} \mathrm{E}\right)$, the capital of Niger, performed twenty measurement flights. The general flight strategy included several fast ascents and descents to sound the vertical atmospheric column up or down to the maximum/minimum flight level (from $6 \mathrm{~km}$ to $300 \mathrm{~m}$ above ground level (a.g.1.)), in order to detect interesting meteorological and particle layering. In addition, 20-30 min long straight and levelled runs (SLRs) or, less frequently, closed triangular patterns were flown at fixed altitudes for aerosol particle collection. An example of flight plan is shown in Saïd et al. (2010).

As described in Reeves et al. (2010) flights from SOPs 1 and $2 \mathrm{a}_{-} 1$ served various objectives of the AMMA science plans via three Intensive Observational Periods (IOPs): IOP 1.1 (Surface-atmosphere: Inter-tropical front and heat low surveys); IOP 1.2 (Surface-atmosphere-aerosol: Squallline related to aerosol emissions surveys); IOP 1.3 (Surfaceatmosphere: North-South land-ocean-atmosphere interactions surveys). A summary of flight information (date, location, aim) is provided in Table 1 .

Most of the flights (fourteen out of nineteen) were conducted in coordination with the AMMA ground-based super-
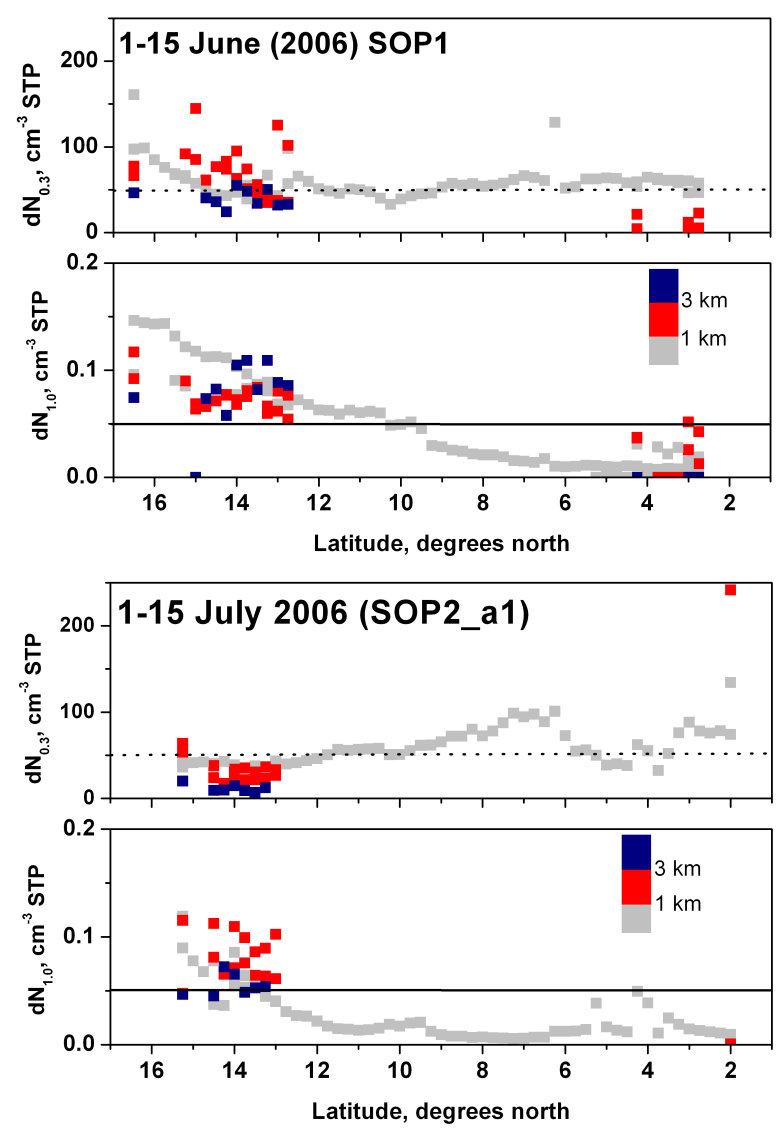

b

Fig. 3. Average number concentrations for particles of diameter larger than $0.3 \mu \mathrm{m}\left(d N_{0.3}\right)$ and for particle of diameter larger than $1 \mu \mathrm{m}\left(d N_{1.0}\right)$ as a function of the latitude. Data have been averaged in bins of $100 \mathrm{hPa}$ of atmospheric pressure and are expressed in $\mathrm{cm}^{-3} \mathrm{STP}$ (standard temperature and pressure, $P=1013.25 \mathrm{hPa}$; $T=20^{\circ} \mathrm{C}$ ). The upper panel (a) corresponds to the SOP1 sampling period and the lower panel (b) to the SOP2_a1 one. The horizontal black dotted line indicates a threshold of $50 \mathrm{~cm}^{-3}$ STP for the $d N_{0.3}$ particle concentration, used to check the ITD shift in latitude as explained in the text. The black solid line refers to the $0.05 \mathrm{~cm}^{-3}$ STP for the $d N_{1.0}$ particle concentration.

site of Banizoumbou $\left(13.5^{\circ} \mathrm{N}, 2.5^{\circ} \mathrm{E}, 250 \mathrm{~m}\right.$ above sea level (a.s.l.), located at about $60 \mathrm{~km}$ east of Niamey (Rajot et al., 2008; Marticorena et al., 2010). In the attempt of accommodating the various IOPs scientific objectives, clearsky conditions prior and post the occurrence of mesoscale convective (MSC) events were sampled preferentially. Due to flight security restrictions, flights were conducted during daytime only. 
Table 2. Range of variability of crustal tracers $\left(\mathrm{Mg}, \mathrm{Al}, \mathrm{Si}, \mathrm{P}, \mathrm{K}, \mathrm{Ca}, \mathrm{Fe}\right.$, and $\mathrm{Ti}$ ) measured for samples collected north of $12^{\circ} \mathrm{N}$. The statistics is restricted to samples for which concentrations are above the average minimum detection limit (MDL). For sake of comparison with previous campaigns in western Africa, the descriptive statistics of the total dust mass estimated from the Al concentrations, as the sum of elemental concentrations and as the sum of elemental concentrations expressed as oxides is also shown. These calculations have been performed only on samples for which elemental Ti was above the MDL. Concentrations are expressed in $\mu \mathrm{g} \mathrm{m}^{-3}$.

\begin{tabular}{|c|c|c|c|c|c|}
\hline & $\begin{array}{l}\text { Average minimum } \\
\text { detection limit (MDL) }\end{array}$ & $\begin{array}{l}\text { Number of data points } \\
\text { higher than MDL }\end{array}$ & Median & Min & Max \\
\hline $\mathrm{Mg}$ & 0.01 & 100 & 0.4 & 0.05 & 3.3 \\
\hline $\mathrm{Al}$ & 0.02 & 100 & 3.8 & 0.7 & 38.4 \\
\hline $\mathrm{Si}$ & 0.03 & 100 & 8.6 & 2.4 & 76.0 \\
\hline $\mathrm{P}$ & 0.01 & 24 & 0.2 & 0.04 & 0.4 \\
\hline K & 0.06 & 73 & 0.7 & 0.3 & 4.9 \\
\hline $\mathrm{Ca}$ & 0.03 & 95 & 1.0 & 0.2 & 7.6 \\
\hline $\mathrm{Fe}$ & 0.04 & 97 & 2.0 & 0.6 & 18.2 \\
\hline $\mathrm{Ti}$ & 0.04 & 51 & 0.6 & 0.2 & 3.1 \\
\hline $\begin{array}{l}\text { Mass calculated from the concentration } \\
\text { of elemental } \mathrm{Al}^{*}\end{array}$ & - & 51 & 73.7 & 8.0 & 468.2 \\
\hline $\begin{array}{l}\text { Mass calculated as sum of elemental } \\
\text { concentrations }\end{array}$ & - & 51 & 22.4 & 5.7 & 147.0 \\
\hline $\begin{array}{l}\text { Mass calculated as sum of elemental } \\
\text { concentrations } \\
\text { (expressed as oxides) }\end{array}$ & - & 51 & 41.6 & 10.1 & 282.3 \\
\hline
\end{tabular}

* Estimated assuming a mean conversion factor of $8.2 \%$.

\section{Results}

\subsection{Aerosol spatial variability}

The north-south gradient of the aerosol particle load observed during the nineteen ATR-42 flights in SOP1 and SOP2_a1 can be explored by looking at the variability of the particle number concentration as a function of latitude (Fig. 3).

Data are number concentrations for particles of diameter larger than $0.3 \mu \mathrm{m}\left(d N_{0.3}\right)$ and for particle of diameter larger than $1 \mu \mathrm{m}\left(d N_{1.0}\right)$ averaged in bins of 0.25 degrees in horizontal resolution and $100 \mathrm{hPa}$ in vertical resolution. Data are then presented for three atmospheric levels: below $1 \mathrm{~km}$, corresponding to the mean boundary layer depth during the campaign; between 1 and $3 \mathrm{~km}$, corresponding to the mean extent of the African Easterly Jet (AEJ) and to the expected maximum dust concentration in the Saharan Air Layer (SAL); and above $3 \mathrm{~km}$, for decreasing concentrations. This distinction has been based on the examination of the aerosol and thermodynamic vertical profiles which will be presented later in the paper.

The total number of $d N_{0.3}$ particles remained lower than $160 \mathrm{~cm}^{-3}$ STP during June 2006 (SOP1, Fig. 3a). North of $12^{\circ} \mathrm{N}$, comparable concentrations were observed in the boundary layer and above. South of $12^{\circ} \mathrm{N}$, the north-south particle concentration at the surface showed no significant gradient but a slight increasing trend towards the north. An isolated maximum at the surface was observed around $6^{\circ} \mathrm{N}$ in correspondence to the position of the town of Cotonou. With over 1.2 million inhabitants and a large active industrial harbor with transiting oil and metals, Cotonou is the economic capital of Benin (Minga et al., 2010).

The $d N_{0.3}$ particle loading during July 2006 (SOP2_a1, Figure 3a) behaved differently. Values remained lower that $100 \mathrm{~cm}^{-3}$ STP with the exception of an isolated maximum $\left(\sim 220 \mathrm{~cm}^{-3} \mathrm{STP}\right)$ observed at $2^{\circ} \mathrm{N}$ above $1 \mathrm{~km}$. This corresponds to the vertical sounding which was performed on 4 July during flight V030, in an area where satellite images (OMI, MODIS, not shown) suggested transport of biomass burning plumes from the Southern Hemisphere. The CO and $\mathrm{O}_{3}$ concentrations measured onboard the aircraft reached $420 \mathrm{ppbv}$ and $100 \mathrm{ppbv}$ at $1500 \mathrm{~m}$, instead of $150 \mathrm{ppbv}$ and $40 \mathrm{ppbv}$ in the boundary layer. Concentrations north of $12^{\circ} \mathrm{N}$ were lower than during SOP1 (below $50 \mathrm{~cm}^{-3} \mathrm{STP}$ ), and that almost independently of altitude. South of $12^{\circ} \mathrm{N}$, concentrations increased between $6^{\circ}$ and $10^{\circ} \mathrm{N}$. A possible explanation for this increase is the presence of numerous small forest fires which were detected during the transect flights.

On the opposite, the comparison of the $d N_{1.0}$ particle number concentration values measured during the SOP1 and the SOP2_a1 periods shows that in the boundary layer the north-south gradient remained consistent during the two flying periods. Highest concentrations were observed towards the north of the domain, decreasing towards the south. This gradient reflects the northward displacement of the ITD from 
June to July. Concentrations higher that $5 \times 10^{-2} \mathrm{~cm}^{-3}$ STP were found down to $10^{\circ} \mathrm{N}$ in June, but only north of $13^{\circ} \mathrm{N}$ during July. The threshold is indicated with the horizontal black line in Fig. 3b. This corresponds to the progressive northward advance of the Monsoon layer, characterized by smaller particles. Observations between $13.5^{\circ} \mathrm{N}$ and $15.5^{\circ} \mathrm{N}$, where the atmospheric column was more frequently sounded, show that concentrations can be elevated also above the surface layer.

Because the elemental composition by bulk analytical techniques such as XRF is largely determined by the coarse fraction, the $d N_{1.0}$ particle distribution reflects the spatial distribution of the elemental concentrations which have been obtained by filter sampling and XRF analysis. As an example, the north-to-south gradient of elemental $\mathrm{Al}$ is shown in Fig. 4.

The lower number of data point is due to the coarser resolution of the filter sampling. In the absence of other significant sources, elemental $\mathrm{Al}$ can be used as a non-ambiguous tracer of mineral dust (Mason, 1966; Taylor, 1986). The crustal origin of the other elements measured above detection limit $(\mathrm{Mg}, \mathrm{Si}, \mathrm{P}, \mathrm{K}, \mathrm{Ca}, \mathrm{Fe}$, and $\mathrm{Ti})$ is put into evidence by calculating their linear regressions with respect to Al. A 2-tailed test of significance shows that the Pearson regression coefficients were comprised between 0.88 and 0.99 for $\mathrm{Mg}$, $\mathrm{Si}, \mathrm{P}, \mathrm{K}, \mathrm{Ti}$ and $\mathrm{Fe}$, but only 0.57 for $\mathrm{Ca}$. This is consistent with the coexistence, in mineral dust, of aluminosilicate species (such as clays, feldspars) traced by $\mathrm{Al}$ and calcium carbonate species (such as calcite, dolomite gypsum) traced by Ca (Kandler et al., 2007; Rajot et al., 2008; Formenti et al., 2008). Good correlations were found between $\mathrm{Ca}$ and $\mathrm{Mg}$ (Pearson regression coefficient of 0.84 ) and between $\mathrm{Ca}$ and $\mathrm{K}$ (Pearson regression coefficient of 0.72).

In order to provide with the range of variability for dust conditions only, Table 2 summarizes the range of variability for samples collected north of $12^{\circ} \mathrm{N}$. For sake of comparison with previous campaigns in western Africa (Formenti et al., 2003; 2008; Rajot et al., 2008; McConnell et al., 2008), Table 2 also reports on the descriptive statistics of the total dust mass.

The calculations have been restricted to the 51 samples for which $\mathrm{Ti}$ was above detection limit. The total dust mass has been estimated in three ways: (i) as the sum of major elemental oxides; (ii) as the sum of elemental concentrations; and (iii) from the $\mathrm{Al}$ elemental concentration considering that $\mathrm{Al}$ accounts for about $8.13-8.36 \%$ of the earth's crust mass (Mason, 1966; Taylor and McLennan, 1985). The three estimates of the mass are highly correlated (Pearson regression coefficient $>0.96$ ), as $\mathrm{Al}$ is one of the major constituents of mineral dust in terms of mass. Nonetheless, the differences between the three estimates are higher than the expected variability in the crustal composition. In the absence of a direct gravimetric measurement, it is not possible to constrain in a robust way the conversion rule allowing estimating the total dust mass. Nonetheless, our experience, in accordance with

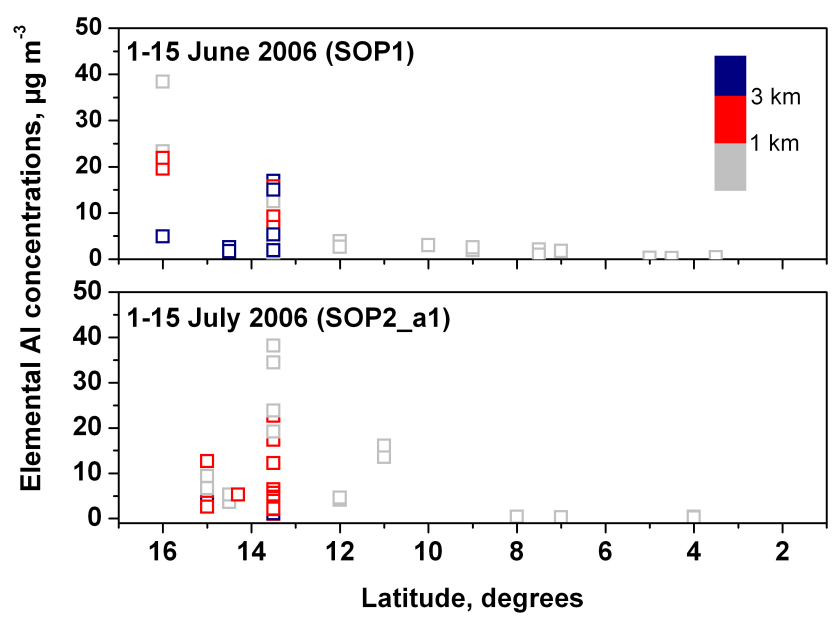

Fig. 4. Elemental $\mathrm{Al}$ concentration $\left(\mu \mathrm{g} \mathrm{m}^{-3}\right)$ as a function of latitude as determined by filter sampling during the SOP1 and SOP2_a1 field campaigns. Data have been colour-coded according to the altitude of sampling.

that of other research groups (Prospero et al., 1981; Prospero, 1999; Klaver et al., 2011) suggests that the conversion from the $\mathrm{Al}$ elemental concentration is a good representation of the dust mass. The uncertainties in the estimate of the dust mass has important implications when one wants to use measured concentrations for comparison with output of emission models, or to calculate the mass scattering or absorption efficiencies of the aerosol.

The elemental concentrations show the same large variability than during previous airborne campaigns in western Africa (see Table 1 in Formenti et al., 2008). However, they are lower than those measured during wintertime in the $\mathrm{Ni}$ amey area during the SOP0 phase (Formenti et al., 2008) and only comparable to those observed for short-range transport conditions such as those encountered offshore Senegal during the Saharan Dust Experiment (SHADE) and Dust Outflow and Deposition to the Ocean (DODO1) airborne campaigns (Formenti et al., 2003; McConnell et al., 2008). As a matter of fact, the long-term record of surface concentration measurements reported by Marticorena et al. (2010) illustrates that dust concentrations in June and July are characterised by mean values of the same order of magnitude as wintertime ones, but by a much higher variability due to the episodic character of both emission (by MSC-driven high winds) and deposition (by MSC-induced precipitation). These authors show that concentrations might vary by five orders of magnitude on a few-minute scale. It is clear that the limited frequency of aircraft sampling, which mostly was conducted at solar midday, at least eight hours later than MSC-driven emissions, under-samples the full variability of the elemental concentrations. In addition, at times, the altitude of SLRs for particle collections had to be accommodated to other scientific requests, and might not have been 

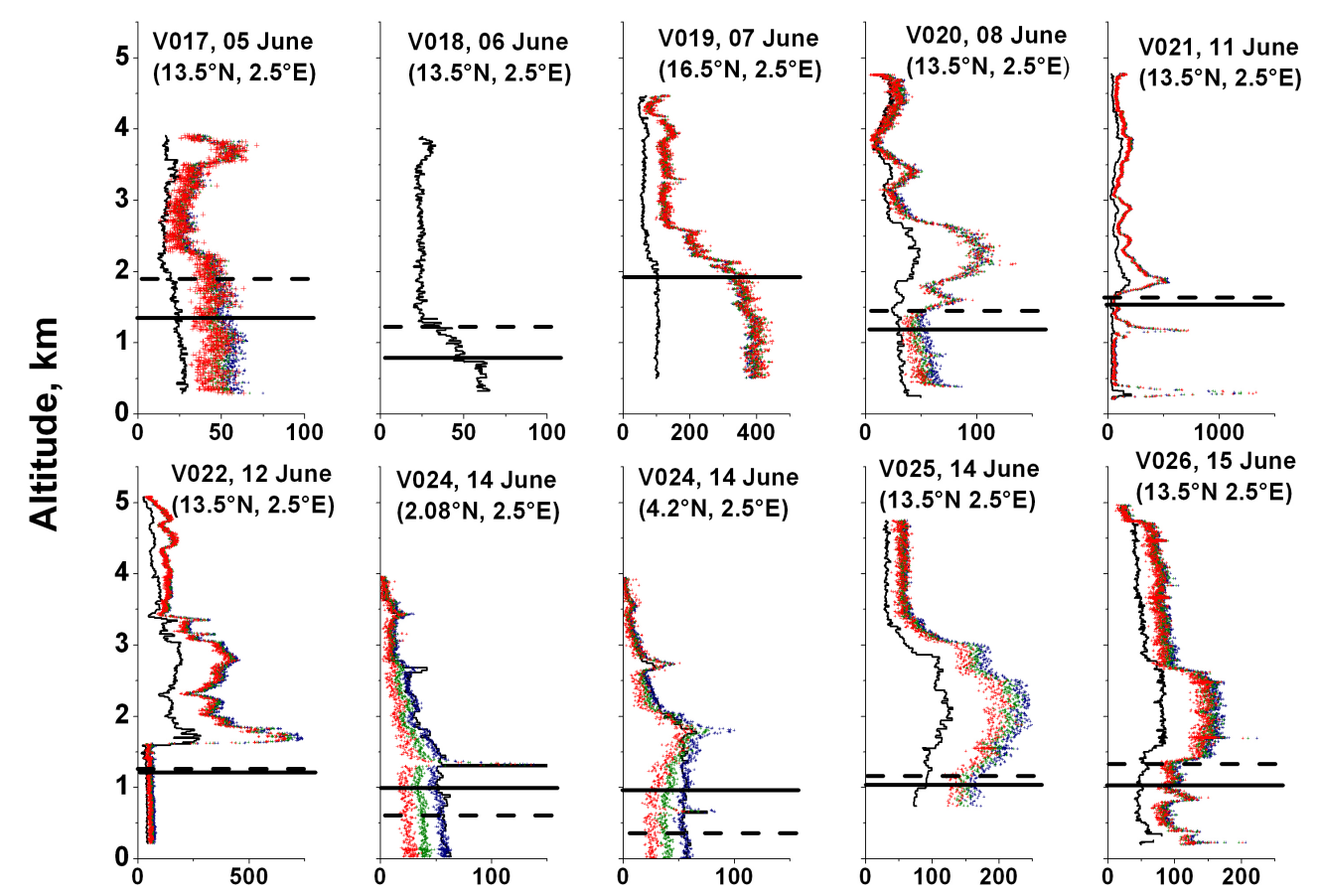

Particle number concentration, $\mathrm{cm}^{-3} \mathrm{STP}$

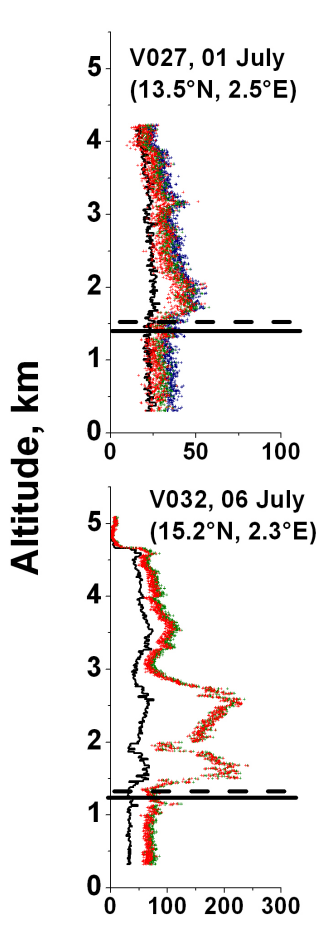

\section{Particle scattering coefficient, $\mathrm{Mm}^{-1}$ STP}
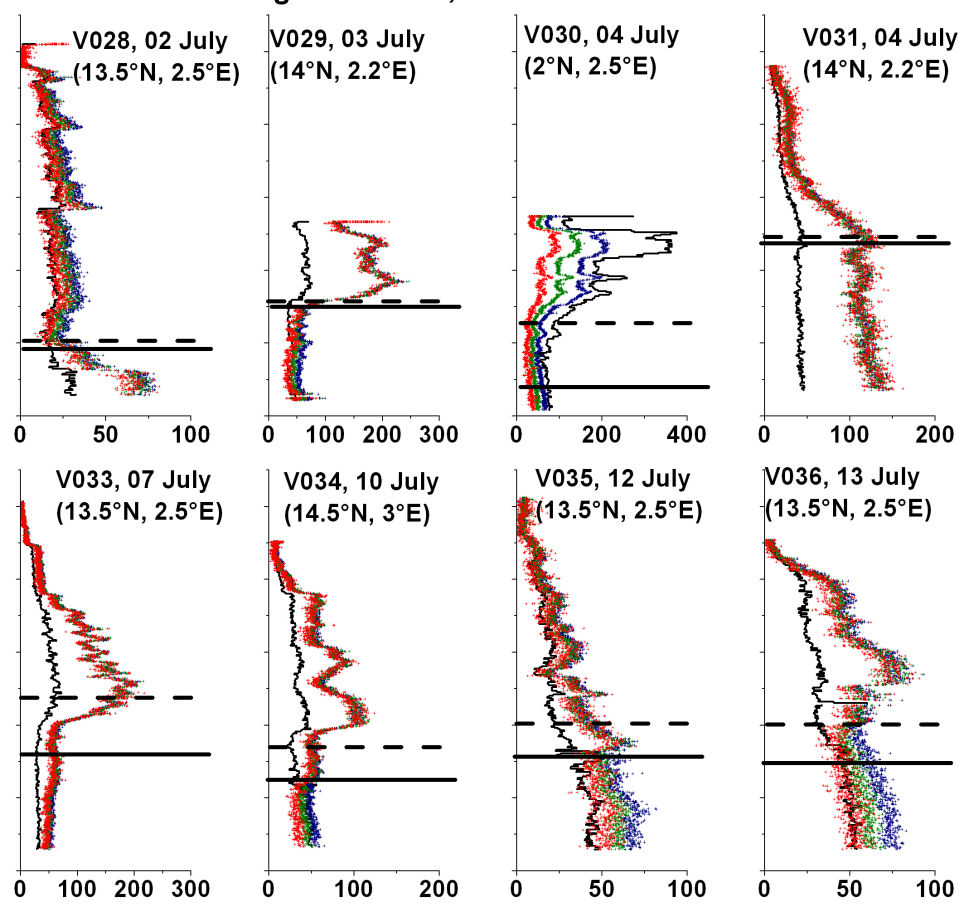

Particle number concentration, $\mathrm{cm}^{-3}$ STP Particle scattering coefficient, $\mathrm{Mm}^{-1}$ STP

Fig. 5. Vertical profiles of $d N_{0.3}$ particle number and of the spectral scattering coefficient $\sigma_{\mathrm{s}}$ at 450,550 , and $700 \mathrm{~nm}$ (blue, green and red crosses, respectively) observed during the SOP1 (upper panel, (a) and SOP2_a1 (lower panel, (b) field phases. Data are expressed in $\mathrm{cm}^{-3}$ and $\mathrm{Mm}^{-1} \mathrm{STP}$ (standard temperature and pressure, $P=1013.25 \mathrm{hPa} ; T=20^{\circ} \mathrm{C}$ ). The heights of the top of the boundary layer $\left(Z_{i}\right.$, solid line) and of the shear level $\left(Z_{\mathrm{S}}\right.$, dotted line) are also indicated. 
chosen at the height where the highest concentrations were observed.

\subsection{Aerosol vertical profiles}

The chronological sequence of the vertical profiles of $d N_{0.3}$ and of the spectral scattering coefficient $\sigma_{\mathrm{s}}$ at 450,550 , and $700 \mathrm{~nm}$ are presented in Fig. 5a and b for the June (SOP1) and July (SOP2_a1) periods. The information relative to the time and geographical location of those profiles is summarized in Table 3.

The variability of the shape and magnitude of the profiles is evident. Particle concentrations varied between 25 and $200 \mathrm{~cm}^{-3}$, whereas plumes where the scattering coefficient $\sigma_{\mathrm{s}}$ reached $800 \mathrm{Mm}^{-1}$ were observed. The spectral dependence of the aerosol scattering provides with information on the size distribution and therefore indirectly on the nature of the aerosol. So, spectrally-neutral plumes are indicative of aerosols such as mineral dust with a significant coarse mode (Formenti et al., 2003; Osborne et al., 2008) whereas plumes for which the spectral dependence of the particle scattering coefficient is well pronounced are due to aerosols dominated by the accumulation mode such as pollution or biomass burning (Formenti et al., 2002; Johnson et al., 2008).

Plumes of elevated concentrations were observed at different altitudes. Layers of thickness variable between 1 and $3.5 \mathrm{~km}$ were observed during flights V017, V018, V019, V026, V028 and V031. Elevated aerosol plumes were observed above $1.5 \mathrm{~km}$ up to approximately $5 \mathrm{~km}$, either as a single layer (flights V025, V026, V030, V033, V036) or by a more stratified structure (flights V020, V021, V022, V024, V029, V032, V034). Layers of very low concentrations decreasing monotonically with height were also observed (profiles during flights V024, V027 and V035). Such diversity is consistent with the climatology of aerosol profiles in the area proposed by Cavalieri et al. (2010) based on ground-based and spaceborne lidar observations. Over land, the aerosol layers were always spectrally neutral, indicating than mineral dust dominated the aerosol load. Over sea (flights V024 and V030) plumes with a more pronounced spectral dependence were observed either close to the surface or above $1 \mathrm{~km}$.

The aerosol vertical structure is strongly related to the thermodynamic structure of the atmosphere. This is depicted by the height of the top of the boundary layer $\left(Z_{i}\right.$, solid line in Fig. $5 a$ and $b)$ and by the shear level $\left(Z_{\mathrm{s}}\right.$, dotted line in Fig. 5a and b) corresponding to the top height of the transition zone between the Monsoon and the Harmattan wind regimes. If $Z_{i}$ is lower than $Z_{\mathrm{s}}$ the boundary layer is well isolated from the SAL. There is no possibility of entrainment, therefore aerosols emitted locally at the surface are confined to the boundary layer and cannot mix with dust transported in the SAL by the AEJ. Aerosol mixing by entrainment is possible when $Z_{i}$ is equal to $Z_{\mathrm{S}}$.

The examination of these thermodynamical discontinuities for the SOP1 and SOP2_a1 periods indicates that, $Z_{i}$ was generally lower than $Z_{\mathrm{s}}$ at the time when the vertical soundings were performed (Fig. 5). The vertical soundings were usually made around midday and the boundary layer went on growing after the sounding. During SOP1, the boundary layer growth made $Z_{i}$ reach $Z_{\mathrm{s}}$ (Saïd et al., 2010) which produced strong moisture exchanges at small scale between the Monsoon layer and the SAL (Canut et al., 2010). However, these exchanges cannot be detected on scalars (such as temperature and water vapour mixing ratio) or particles, when sampled at time resolutions larger than $1 \mathrm{~s}$. Even if there is some exchange between the mixed layer and the SAL, only the average content of the mixing will be detected. The only mean to estimate the exchanges would have been to sample the time evolution of the concentration, which was not done. During SOP2_a1, $Z_{i}$ less often reached $Z_{\mathrm{s}}$ due to weaker surface heat fluxes, especially when the flights occurred just after rainy episodes (see V033, V034 and V036). It was also the case for flights performed over the sea (V024 and V030).

\subsection{Discussion of case studies}

The vertical profiles of particle concentration and particle scattering coefficient and the chemical composition will be used to identify the aerosol origin and residence time in the atmosphere.

Some elemental ratios are particularly informative in this sense. The Si/Al ratio represents the content of aluminosilicate types of minerals (clays and feldspars) and quartz $\left(\mathrm{SiO}_{2}\right)$, whereas the $\mathrm{Fe} / \mathrm{Ca}$ ratio that of iron-rich minerals (i.e., iron oxides) with respect to calcium carbonates (calcite, dolomites) and calcium sulphates (gypsum). Elemental $\mathrm{Fe}$ and $\mathrm{Ca}$ are present in alumino-silicate minerals too, but in much lower proportions, and this does not alter the use of the $\mathrm{Fe} / \mathrm{Ca}$ ratio to trace the proportions of iron-rich and calcium-rich minerals. The regional variability of these ratios is demonstrated in various publications (Chiapello et al., 1997; Claquin et al., 1999; Kandler et al., 2007; Formenti et al., 2003; 2008; McConnell et al., 2008; Rajot et al., 2008). The Fe/Ca ratio allows distinguishing Saharan from Sahelian dust, the former having lower $\mathrm{Fe} / \mathrm{Ca}$ ratio $(<\sim 1)$ than the latter $(>\sim 1)$. In particular, the Bodélé depression, considered to be one of the largest single source region in Africa (Prospero et al., 2002; Bristow et al., 2010), is poor in Fe and therefore is characterised by a $\mathrm{Fe} / \mathrm{Ca}$ ratio ranging between $\sim 1$ and 4.5 due to large composition variability (Formenti et al., 2008; Bristow et al., 2010). Whenever possible, the iron oxide content will be provided. However, owing to relatively low concentrations, the latter could be determined only on a very limited number of samples.

\subsubsection{Background oceanic and continental conditions}

Reference clean background conditions were encountered on a few occasions during the field campaign. 
Table 3. Summary of information (date, location, elevation) of the vertical profiles performed by the ATR-42 during the research flights of the AMMA SOP1 and SOP2_a1 field phases. The height of the top of the boundary layer $\left(Z_{i}\right)$ and the shear level height $\left(Z_{\mathrm{s}}\right)$ is also indicated.

\begin{tabular}{|c|c|c|c|c|c|c|c|c|}
\hline Date & Flight ID & Location & $\begin{array}{l}\text { Start time } \\
\text { (UTC) }\end{array}$ & $\begin{array}{l}\text { End time } \\
\text { (UTC) }\end{array}$ & $\begin{array}{l}\text { Min altitude } \\
\text { (km a.s.l.) }\end{array}$ & $\begin{array}{l}\text { Max altitude } \\
\text { (km a.s.l) }\end{array}$ & $\begin{array}{c}Z_{i} \\
\text { (km a.s.l.) }\end{array}$ & $\begin{array}{c}Z_{\mathrm{s}} \\
\text { (km a.s.l.) }\end{array}$ \\
\hline 5 June & V017 & Banizoumbou & $12: 37$ & 13:01 & 0.3 & 4.3 & 1.4 & 1.8 \\
\hline 6 June & V018 & Banizoumbou & $11: 18$ & 11:42 & 0.3 & 4.3 & 0.8 & 1.2 \\
\hline 7 June & V019 & $16.5^{\circ} \mathrm{N}, 2.5^{\circ} \mathrm{E}$ & $13: 40$ & 14:07 & 0.3 & 5.0 & 1.9 & Not defined \\
\hline 8 June & V020 & Banizoumbou & $11: 18$ & $11: 42$ & 0.3 & 5.3 & 1.3 & 1.5 \\
\hline 11 June & V021 & Banizoumbou & $11: 48$ & 12:09 & 0.3 & 5.3 & 1.5 & 1.5 \\
\hline 12 June & V022 & Banizoumbou & $11: 31$ & 12:10 & 0.3 & 5.6 & 1.2 & 1.2 \\
\hline \multirow{2}{*}{14 June } & \multirow{2}{*}{ V024 } & $2.1^{\circ} \mathrm{N}, 2.5^{\circ} \mathrm{E}$ & $8: 32$ & $8: 48$ & 0.3 & 4.3 & 0.6 & 1.0 \\
\hline & & $4.2^{\circ} \mathrm{N}, 2.5^{\circ} \mathrm{E}$ & 09:48 & 10:01 & 0.3 & 4.3 & 0.4 & 1.0 \\
\hline 14 June & V025 & Banizoumbou & $15: 12$ & $15: 30$ & 0.7 & 5.3 & 1.1 & 1.1 \\
\hline 15 June & V026 & Banizoumbou & 10:19 & 11:03 & 0.3 & 6.0 & 1.0 & 1.4 \\
\hline 1 July & V027 & Banizoumbou & $11: 38$ & 12:04 & 0.3 & 4.7 & 1.4 & 1.4 \\
\hline 2 July & V028 & Banizoumbou & $11: 52$ & $12: 27$ & 0.3 & 6.0 & 0.8 & 0.9 \\
\hline 3 July & V029 & Niamey to $14^{\circ} \mathrm{N}, 2.2^{\circ} \mathrm{E}$ & $11: 34$ & $11: 50$ & 0.3 & 2.8 & 1.6 & 1.6 \\
\hline 4 July & V030 & $2^{\circ} \mathrm{N}, 2.5^{\circ} \mathrm{E}$ & 09:39 & 09:57 & 0.3 & 3.0 & 0.4 & 1.3 \\
\hline 4 July & V031 & $14^{\circ} \mathrm{N}, 2.2^{\circ} \mathrm{E}$ & $16: 50$ & $17: 20$ & 0.3 & 5.3 & 2.4 & 2.4 \\
\hline 6 July & V032 & $15.2^{\circ} \mathrm{N}, 2.3^{\circ} \mathrm{E}$ & $12: 27$ & $12: 35$ & 0.3 & 5.2 & 1.3 & 1.4 \\
\hline 7 July & V033 & $13.5^{\circ} \mathrm{N}, 2.5^{\circ} \mathrm{E}$ & 13:51 & $14: 21$ & 0.3 & 5.2 & 1.6 & 2.4 \\
\hline 10 July & V034 & $14.5^{\circ} \mathrm{N}, 3^{\circ} \mathrm{E}$ & $10: 45$ & 11:16 & 0.3 & 5.0 & 1.2 & 1.7 \\
\hline 12 July & V035 & Banizoumbou & 13:02 & $13: 35$ & 0.3 & 5.6 & 1.6 & 2.0 \\
\hline 13 July & V036 & Banizoumbou & $12: 15$ & $12: 41$ & 0.3 & 5.0 & 1.5 & 2.0 \\
\hline
\end{tabular}

Vertical soundings during flight V024 (Fig. 5a) represent pristine air oceanic conditions over the Gulf of Guinea at $2^{\circ}$ and $4^{\circ} \mathrm{N}$. In this figure, the particle number concentration is merged with the $450 \mathrm{~nm} \sigma_{\mathrm{s}}$ curve. Aerosol number concentrations $d N_{0.3}$ were almost constant around $50 \mathrm{~cm}^{-3} \mathrm{STP}$ up to $1-1.5 \mathrm{~km}$. So the marine boundary layer that was only $500 \mathrm{~m}$ deep exhibited the same particle composition as the whole Monsoon layer that extended up to $1 \mathrm{~km}$, suggesting that the boundary layer was deeper on the previous days and that the air mass had not changed. Above, the aerosol number concentrations decreased rapidly to zero. In the same way, the particle scattering coefficient averaged at around $40 \mathrm{Mm}^{-1}$ at $550 \mathrm{~nm}$ within the Monsoon layer. The accentuated spectral dependence indicates the predominance of accumulation mode particles in the size distribution. The small peaks at $1.5,1.8$ and $2.8 \mathrm{~km}$ correspond to peaks in the $\mathrm{O}_{3}$ vertical profiles and to a slight increase in the $\mathrm{CO}$ sounding. This suggests that these are aged plumes of combustion origin. As it will be discussed in the following paragraph, an episode of transport of biomass burning was observed at $2^{\circ} \mathrm{N}$ during flight V030. In the Monsoon layer this flight otherwise represented background oceanic condition.

Profiles collected during flights V017, V027, and V035 (5 June, 1 and 12 July) represent background continental conditions north of $13^{\circ} \mathrm{N}$. Conditions sampled during flights V017 and V035 corresponded to the cleaning of the atmosphere following the passage of rather localized precipitating con- vective systems which occurred over Banizoumbou on 4 June and 11 July (6 and $20 \mathrm{~mm}$ of cumulated rain, respectively). These profiles were characterized, at all altitudes, by $d N_{0.3}$ and $\sigma_{\mathrm{s}}$ values lower than $50 \mathrm{~cm}^{-3}$ and $75 \mathrm{Mm}^{-1}$, respectively. These values are comparable to the pristine oceanic conditions, except for the fact that the ratio $\sigma_{\mathrm{s}, 550 \mathrm{~nm}} / d N_{0.3}$ was lower than $1 \mathrm{Mm}^{-1} / \mathrm{cm}^{-3}$ for oceanic conditions but higher than 1 for continental conditions. As it will be shown in Sect. 4.3, this suggests that the number size distributions are different. As a matter of fact, background continental conditions are enriched in particles larger than $0.5 \mu \mathrm{m}$ in diameter whereas background oceanic conditions are enriched in fine particles smaller than $0.5 \mu \mathrm{m}$. This suggests that the marine influence is minor at Banizoumbou.

Notable differences are also reflected in the mean Al concentrations. In the boundary layer, these were 0.26 $( \pm 0.09) \mu \mathrm{g} \mathrm{m}^{-3}$ for flights over ocean (V024 and V030) but varied between $2.0( \pm 0.4) \mu \mathrm{g} \mathrm{m}^{-3}$ and $4.5( \pm 0.2) \mu \mathrm{g} \mathrm{m}^{-3}$ for flights V017, V027 and V035. The mean Si/Al and Fe/Ca values for these three flights were close to typical values for mineral dust and also very similar. The measured $\mathrm{Si} / \mathrm{Al}$ values were $2.1( \pm 0.1), 2.2( \pm 0.1)$ and $2.2( \pm 0.1)$, respectively, and the Fe/Ca ratio values were $2.3( \pm 0.6), 2.2( \pm 0.5)$ and $1.8( \pm 0.6)$. Only the $\mathrm{Si} / \mathrm{Al}$ ratios were above detection limits on flights over the ocean and equal to $2.5( \pm 0.2)$. 


\subsubsection{Advection of southern hemispheric biomass burning}

An episode of advection of southern hemispheric biomass burning in the Northern Hemisphere was detected at $2^{\circ} \mathrm{N}$ during flight V030 on 4 July (Fig. 5b).

Above $1.5 \mathrm{~km}$, particle concentration $d N_{0.3}$ was as high as $350 \mathrm{~cm}^{-3} \mathrm{STP}$, and the particle scattering coefficient at $550 \mathrm{~nm}$ averaged at $100 \mathrm{Mm}^{-1}$. Unfortunately the layer was only sounded during the vertical profile, and not sampled at constant altitude, disabling further investigation of its properties, notably of the absorption coefficient and of the aerosol composition. Assuming the average single scattering albedo value of 0.91 obtained at $550 \mathrm{~nm}$ by Haywood et al. (2003b) for Southern Hemisphere aged biomass burning, the scattering profile can be converted in extinction, which then can be integrated between 1.5 and $2.9 \mathrm{~km}$ to yield a lower limit estimate of the column aerosol optical depth. By doing so, the integrated extinction is 0.14 , lower than the aerosol optical depth values reported for advected biomass burning during the dry season (Johnson et al., 2008). By comparing the profiles in this work and that of Johnson et al., 2008), it is nevertheless clear that the values of extinction are comparable. On the contrary, the profile ceiling is too low with respect to the full extent of the biomass burning plumes, which has been found to extend up to $6 \mathrm{~km}$ (Fiedler et al., 2011). The bottom altitude of the biomass burning plume is in agreement with that shown for transported Northern Hemisphere biomass burning in the dry season (Kim et al., 2009; Léon et al., 2009). This is also in agreement with the vertical profile of the excess in $\mathrm{O}_{3}$ concentrations presented by Mari et al. (2008) and Thouret et al. (2009) both indicating that transported plumes are generally found around $2 \mathrm{~km}$.

\subsubsection{Local erosion events}

Of the sixteen erosion events detected in Banizoumbou, only two were followed by a flight of the ATR-42.

Flight V018 on 6 June followed a non-precipitating, rather local, MCS which occurred at $03 \mathrm{~h} 00$ UTC on the previous night. Erosion was only moderate, the number of saltating grains measured at Banizoumbou only reaching 2000 counts per $10 \mathrm{~s}$. In correspondence, the record of particle backscattering provided by the micro-pulsed lidar (MPL) of the Atmospheric Mobile Facility (AMF) of the Atmospheric Radiation Measurement (ARM) at the Niamey airport (available online at http://www.arm.gov/sites/amf/nim/ instruments) showed a layer of uplifted aerosols below $1 \mathrm{~km}$ between 03h00 and 07:00 UTC, and then a more complex structure with two layers below and above $1 \mathrm{~km}$ converging into one only layer as time progressed and the solar warming increased the height of the boundary layer. By 16:00 UTC, only one layer was evident between 1 and $4 \mathrm{~km}$. In fact the boundary layer wind had turned from Monsoon to Harmattan during the afternoon, following the southern retraction of the ITD, due to surface convection (Saïd et al., 2010).

Flight V028 on 2 July followed a larger organised MCS originated on the Aïr massif. This system reached Banizoumbou just after midnight on 1 July, provoking intense particle saltation (number of saltating particles up to 5000 counts per $10 \mathrm{~s})$, but also intense rain $(17 \mathrm{~mm}$ of accumulated precipitation).

These observations are consistent with the vertical profiles of $d N_{0.3}$ particle number concentrations and of the $\mathrm{Fe} / \mathrm{Ca}$ and $\mathrm{Si} / \mathrm{Al}$ ratios shown in Fig. 6, as well as of that of the scattering coefficient $\sigma_{\mathrm{s}}$ in Fig. 5a and b.

For flight V018 the enrichment in $d N_{0.3}$ in the boundary layer below $0.9 \mathrm{~km}$ is evident when compared to the background continental conditions. These are shown by the red line illustrating the $d N_{0.3}$ particle concentration during flight V017. The enrichment in particle concentration is less marked for flight V028, possibly due to enhanced depletion by wash-out and rain-out associated with the MCS. In this case, the scattering profile shown in Fig. 5b, and its comparison to that obtained on the previous day (flight V027, 1 July) is more informative.

Nonetheless, in the two cases, it is clear that the aerosol layer is confined to the surface below $1 \mathrm{~km}$ and well separated from the free troposphere. The strong inversion on top of the mixed layer restricts mixing and vertical redistribution of locally-emitted dust (the transition layer between the mixed layer and the SAL is at least $600 \mathrm{~m}$ deep for flight V018 during the aircraft vertical ascent, even if there is some mixing afterwards (Saïd et al., 2010). The proximity of the ITD noticed before is also a source of local dust lifting, since the ITD is an area of convergence between the two opposite flows.

For both flights, differences in the surface and the elevated layers are also evident in the vertical gradient of the $\mathrm{Fe} / \mathrm{Ca}$ and $\mathrm{Si} / \mathrm{Al}$ ratios (Fig. 6). For these two flights, the $\mathrm{Fe} / \mathrm{Ca}$ ratio averaged at 7.4 in the mixed layer. This should indicate enrichment in $\mathrm{Fe}$ and depletion in $\mathrm{Ca}$ which is consistent with the local Sahelian origin of mineral dust. Observation on samples collected during the day at the ground-based site Banizoumbou are also consistent in showing elevated values of the $\mathrm{Fe} / \mathrm{Ca}$ above 10 . In addition, the quantification of the iron oxide content was possible for two samples, one collected in the local erosion dust layer and one in background conditions. The ratio between $\mathrm{Fe}$ in the form of oxide and total $\mathrm{Fe}$ is 0.69 and 0.52 , respectively. These values are consistent with those observed on the ground at Banizoumbou (J. L. Rajot, unpublished data), and also with those reported by Formenti et al. (2008) concerning the wintertime ground-based and airborne AMMA campaigns. Depending on the way that the total dust mass is estimated, the Fe content in the local dust produced by erosion vary between 3 and $9 \%$, the lower boundary obtained when the total mass is estimated from elemental $\mathrm{Al}$ and the upper boundary is obtained when the total mass is estimated as the sum of the elemental 

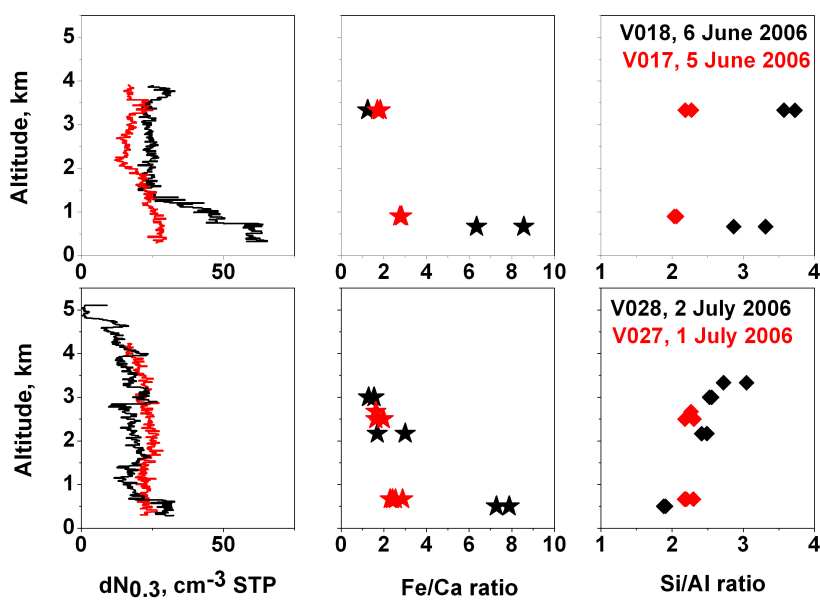

Fig. 6. Vertical profile of the $d N_{0.3}$ particle number concentrations at STP conditions (left panel), Fe/Ca elemental ratio (central panel) and $\mathrm{Si} / \mathrm{Al}$ elemental ratio (right panel) for the local dust erosion episodes observed over Banizoumbou on 6 June (flight V018, upper row) and 2 July (flight V028, lower row). As term of comparison, the red lines and points represent the $d N_{0.3}$ particle number concentrations at STP conditions, and the $\mathrm{Fe} / \mathrm{Ca}$ and SI/Al elemental ratios for flights V017 and V027 conducted the day before each of those flights.

concentrations. This is of course a very large spread which has implication for model calculation of the optical and radiative properties of mineral dust. Above, in the free troposphere, the $\mathrm{Fe} / \mathrm{Ca}$ ratios were much lower, around 1.2 and 1.5 for flight V018 and V028, respectively, as expected for Saharan dust (Kandler et al., 2007). No estimate of the Fe oxide content could be achieved in this layer.

It might be surprising to notice that, despite the $\mathrm{Fe} / \mathrm{Ca}$ ratios being very close, the $\mathrm{Si} / \mathrm{Al}$ ratios in the mixed layer are different (3.1 and 1.9, respectively for flight V018 and for flight V028). These differences might be linked to the different size distribution, which will be discussed in section 4.4. As a matter of fact, the local dust layer of flight V018 is richer in coarser particles than that of flight V028, possibly because of wet deposition which occurred prior this second flight (see Sect. 4.3). As a consequence, during flight V018 the fraction of large quartz particles, which are characteristic of the mineralogy of Sahelian soils (Caquineau et al., 2002), are enriched with respect to the dominantly clays, whereas during flight V028 they were depleted by wash-out. The $\mathrm{Fe} / \mathrm{Ca}$ ratio remained invariant, suggesting that both $\mathrm{Fe}$ and $\mathrm{Ca}$ are associated to particles smaller than $3 \mu \mathrm{m}$. This is consistent with the fact that both structural iron and iron oxides are associated to sub micron clay particles, mostly kaolinite (Greenland et al., 1968; Caquineau, 1997), whereas Ca has been previously found as an impurity in the composition of locally-emitted illite clay (Caquineau, 1997).
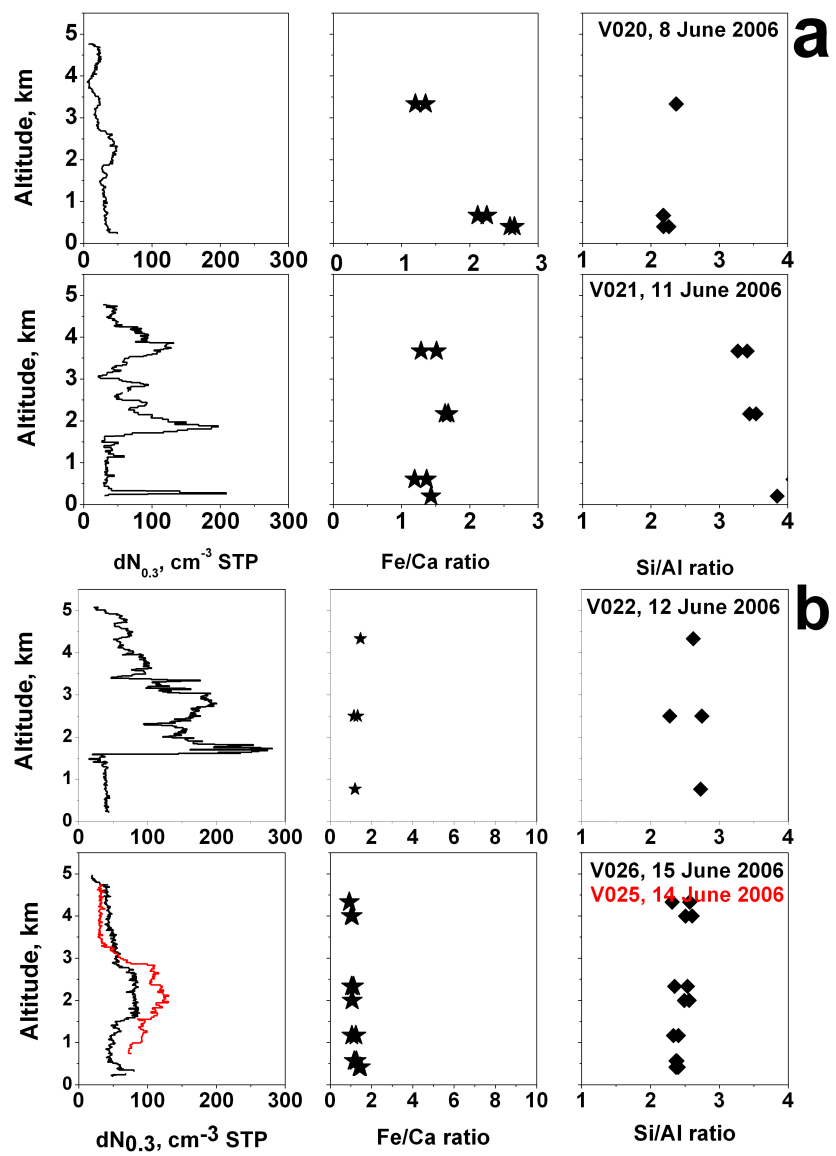

Fig. 7. Vertical profile of the $d N_{0.3}$ particle number concentrations at STP conditions (left panel), Fe/Ca elemental ratio (central panel) and $\mathrm{Si} / \mathrm{Al}$ elemental ratio (right panel) for the Saharan dust episode observed in the proximity of Banizoumbou during the period 9-15 June. Panel (a) shows the vertical profiles for 8 June (flight V020, upper row) and 11 June (flight V021, lower row), whereas panel (b) shows the vertical profiles for 12 June (flight V022, lower row), and 14-15 June (flights V025, in red, and V026, in black).

\subsubsection{Saharan dust transport}

An episode of transport of Saharan dust occurred from 9 to 15 June, when the Niamey-Banizoumbou area experienced a persistent easterly flow, transporting mineral dust from the Bodélé depression in Chad and the Sudanese region (Flamant et al., 2009). These dust laden air masses were transported over Niger where, starting from 11 June, they were sampled by the ATR-42 (flights V021, V022, V025, and V026). The relevance of this episode of transport at the regional scale is highlighted also by the satellite images provided in Cuesta et al. (2008) showing that the dust from Bodélé reached also Tamanrasset in Algeria $\left(\sim 22.8^{\circ} \mathrm{N}\right)$. The episode is also evident in the times series for Banizoumbou and Cinzana (AOD values up to 2 after DOY 162) and to a lesser extent in that measured at Djougou (AOD up to 1). 
The presence of an elevated dust layer extending from 1 to $4 \mathrm{~km}$, in agreement with the indications of back-trajectory calculations reported by Flamant et al. (2009), is evident in the corresponding vertical profiles in Fig. 5a. A more detailed view of the particle concentration and the chemical composition is shown in Fig. 7, illustrating the situation prior the beginning of the episode (8 June, flight V020), on the first two days of the episode (11 and 12 June, V021 and V022), and at the end of the episode (14 and 15 June, V025 and V026).

The complexity and magnitude of the dust layer evolved with time. Highest particle concentrations (up to $250 \mathrm{~cm}^{-3}$ ) and scattering values (up to $600 \mathrm{Mm}^{-1}$ ) were observed during 11 and 12 June, more than twice as much as the values observed prior the beginning of the period on 8 June (flight V020). The dust layers during 11 and 12 June also showed a complex structure with several sub-plumes less than 1-km deep. Lower values (less than $100 \mathrm{~cm}^{-3}$ and $200 \mathrm{Mm}^{-1}$ ) were observed then during 14 and 15 June (Fig. 5a), when the dust layer appearance became less stratified and more resembling the classical structure of the SAL as described by Prospero and Carlson (1972) and Carlson and Prospero (1972). From the dynamic and thermodynamic point of view, the bottom of the elevated dust layers coincided with $Z_{\mathrm{S}}$, the shear level between the Monsoon flow and the AEJ, which most of the time also coincided with $Z_{i}$, the top of the boundary layer. As expected for the SAL, the dust plumes were associated with strong easterly winds, low humidity and stable conditions. They were decoupled from the Monsoon conditions below.

Figure 7 also shows the vertical profile of the $d N_{0.3}$ particle concentration and the chemical composition for flight V026, which was conducted above Banizoumbou on 15 June 2006. In this case, despite the enrichment in particle concentration in the surface layer, the $\mathrm{Fe} / \mathrm{Ca}$ and $\mathrm{Si} / \mathrm{Al}$ ratios are close to values expected for Saharan dust, excluding the contribution of local emission to the aerosol load in the boundary layer. The surface peak during flight V026, as that during flight V021, is due to local pollution possibly from the Niamey area.

These considerations are confirmed by the analysis of the elemental composition. As previously noted, the $\mathrm{Si} / \mathrm{Al}$ mean value for flight V021 is outstanding (3.7 \pm 0.3 ), reflecting the Bodélé origin of the dust. The soil of the Bodélé depression is made of clays, diatom frustules and detrital quartz sand grains (Mounkaila, 2006; Moreno et al., 2006; Todd et al., 2008). The enrichment of $\mathrm{Si}$ in the elemental composition of dust transported from Bodélé to the ground-based site of Banizoumbou has been reported by Rajot et al. (2008) and Formenti et al. (2008) for the wintertime AMMA SOP0 field phase. On the following days, $12-15 \mathrm{June}$, the $\mathrm{Si} / \mathrm{Al}$ dropped to values closer to typical Saharan dust $(\sim 2.5)$, reflecting the fact that the intensity of dust emission from Bodélé was decreasing (Flamant et al., 2009). The corresponding values for the $\mathrm{Fe} / \mathrm{Ca}$ ratio were close to one. Unfortunately, no di-

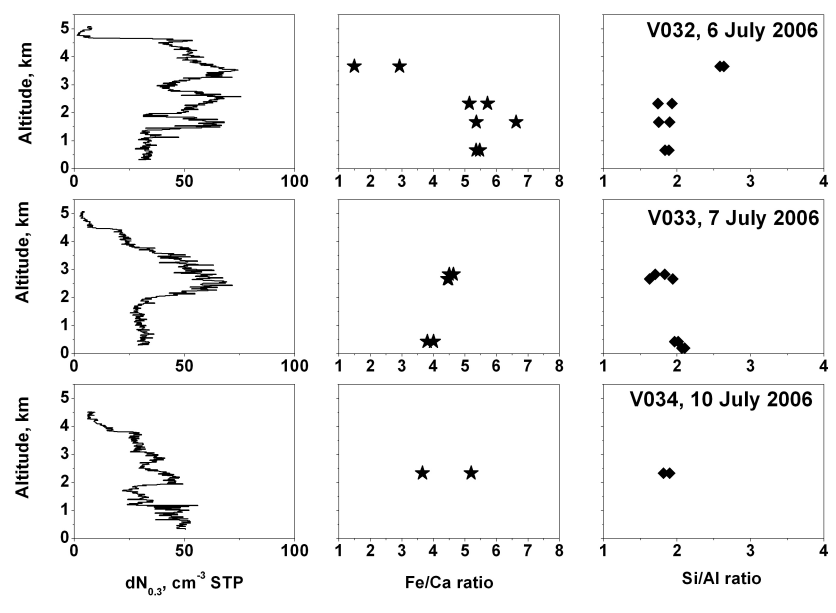

Fig. 8. Vertical profile of the $d N_{0.3}$ particle number concentrations at STP conditions (left panel), Fe/Ca elemental ratio (central panel) and $\mathrm{Si} / \mathrm{Al}$ elemental ratio (right panel) for the Sahelian dust uplift and transport episodes observed north of Banizoumbou on 6 July (flight V032, upper row), 7 July (flight V033, mid-row) and 10 July (flight V034, lower row) during a Sahelian uplift and transport event.

rect measurements of the iron oxide content are available for this episode. One should note than the $\mathrm{Fe} / \mathrm{Ca}$ ratio measured in the boundary layer prior the beginning of the episode was higher than 3, likely as the consequence of some minor local dust emission which had occurred the previous night.

Finally, because of the ubiquitous presence of those tracers in the major minerals constituting mineral dust, the use of the elemental composition might mask some of the differences in the dust composition in the boundary layer and the SAL.

\subsubsection{Sahelian dust transport}

An episode of uplift and transport of Sahelian dust was sampled north of Banizoumbou in the period between 6 and 10 July. Flights V032, V033 and V034 were conducted on two consecutive days (06 and 07 July for V032 and V033, respectively) and then on 10 July for V034, in the area east of Banizoumbou between $13^{\circ}$ and $15.5^{\circ} \mathrm{N}$. During this period the ITD remained north of $17^{\circ} \mathrm{N}$. These flights were preceded by a convective system which had passed on the flight area the previous day and had caused $7 \mathrm{~mm}$ of rain and by a large MSC which had appeared over the north of Nigeria in the late afternoon of 5 July and that caused intense and long-lasting (more than 1 hour) saltation in Banizoumbou. This first local erosion episode was followed daily by other similar but less intense occurrences until 11 July, when a large precipitating MSC (19 mm of cumulated rain) washed the aerosol out. On the next day (13 July, flight V036), dust transport within the SAL was reinitiated.

The vertical profiles of $d N_{0.3}$ particle concentration and the $\mathrm{Fe} / \mathrm{Ca}$ and $\mathrm{Si} / \mathrm{Al}$ ratios are shown in Fig. 8. This 
figure illustrates the vertical variability in shape and magnitude in the particle concentration profiles. The same variability appears when examining the vertical profiles of $\mathrm{Fe} / \mathrm{Ca}$ and Si/Al ratios, in particular regarding flight V032. The dust layer for this flight extended between 1.5 and $4.8 \mathrm{~km}$, with a three sub-layer structure between 1.5 and $2 \mathrm{~km}$, between 2 and $3 \mathrm{~km}$, and then between 3 and $4.8 \mathrm{~km}$. The $\mathrm{Fe} / \mathrm{Ca}$ and $\mathrm{Si} / \mathrm{Al}$ ratios for the first two sub-layers were around 5.5 and 1.8 , respectively. Above $3 \mathrm{~km}$, the $\mathrm{Fe} / \mathrm{Ca}$ and $\mathrm{Si} / \mathrm{Al}$ ratios were around 2.0 and 2.7. Differences are found also in the volume size distribution (not shown). The upper layer has a significantly different volume distribution with a less important coarse fraction that the layers below. This is consistent with the hypothesis of a more distant origin and therefore a higher transport time to the sampling point.

All together with the fact that the lowest two sub-layers were moister than the upper one, this suggests that the dust layer is not homogeneous in origin but is in reality a mixture between Saharan dust transported by the easterly winds within the SAL and Sahelian dust that has been emitted by erosion by the MCS and uplifted from the surface by convective updraft. Note in fact that the $\mathrm{Fe} / \mathrm{Ca}$ and $\mathrm{Si} / \mathrm{Al}$ ratios in the Monsoon layer below $1 \mathrm{~km}$ are of the same order of magnitude than within the lowest Sahelian dust sub-layer which proves that the Saharan-Sahelian mixing occurred upstream and is not a local phenomenon. The fact that the number concentration is different below from above the Monsoon top will be discussed in Sect. 4.4. On the following days, the shape of the vertical profile of the $d N_{0.3}$ particle concentration changed. However, the $\mathrm{Fe} / \mathrm{Ca}$ and $\mathrm{Si} / \mathrm{Al}$ ratios remained unchanged to values around 4 and around 2, respectively. Unfortunately no iron oxide measurement was possible in these layers.

\subsubsection{Saharan atmospheric boundary layer (SABL)}

Profiles collected during flights V019 (07 June) corresponded to the northern excursion of the ATR-42 relative to the ITD position. Flight V019 was entirely dedicated to the investigation of the vertical and horizontal structure of the ITD. With this aim, the aircraft was flown north of the ITD (located at $15.25^{\circ} \mathrm{N}$ at the Niamey longitude) up to $16.5^{\circ} \mathrm{N}$ in Mali, where a vertical profile was performed.

The resulting vertical profile (Fig. 5a) is strikingly different from that observed during the previous cases. The surface dust layer extended up to about $2.5 \mathrm{~km}$, above the top of the mixed layer $Z_{i}$ found at $1.9 \mathrm{~km}$. The concentrations decreased by a factor of 3 above $2.5 \mathrm{~km}$, but still the dust layer was present up to at least $4.5 \mathrm{~km}$. These dust layers corresponded to moderately-to-high easterly winds and very low water vapour mixing ratio. The lower layer was unstable and slightly moister that the upper one, which was also characterised by higher wind speed. These observations agree with the description of dry convection conditions north of the ITD described by Cuesta et al. (2008).
From the chemical point of view, flight V019 was characterised by the highest concentration values of elemental Al. For logistic reasons, unfortunately filter samples were collected only at the very bottom (below $1 \mathrm{~km}$ asl) or at the very top $(\sim 3.8 \mathrm{~km})$ of the profile and are not very informative of the vertical variability of the chemical composition. These are shown in Fig. 9.

Samples collected at the very bottom showed ratios $\mathrm{Si} / \mathrm{Al}$ $\sim 2$ and $\mathrm{Fe} / \mathrm{Ca} \sim 4$. This is consistent with the rather local south Saharan origin of the dust, as confirmed by satellite images (MSG/SEVIRI, not shown). In this layer, the ratio between $\mathrm{Fe}$ in the form of oxide and total $\mathrm{Fe}$ was 0.64 at the lowest altitude and 0.58 at $3.8 \mathrm{~km}$. Depending on the way that the total dust mass is estimated, the Fe content varies between 3.3 and $11 \%$, the lowest value obtained when the dust mass is estimated from elemental $\mathrm{Al}$ and the upper value is obtained when the dust mass is estimated as the sum of the elemental concentrations.

It is interesting to notice that a similar vertical structure was observed on the end of flight-profile which was performed on 4 July during flight V031. This flight ended with a vertical sounding of opportunity at $14^{\circ} \mathrm{N}$, well south of the ITD (located at around $17^{\circ} \mathrm{N}$ ), as the entire flight was rather dedicated to the exploration of the north-south gradient of the surface Monsoon layer over Benin. The examination of the thermodynamic profiles and satellite indicates that the entire dust layer is included in the Monsoon layer (and $Z_{\mathrm{s}}=Z_{i}$ ) which extended up to $2.5 \mathrm{~km}$ (westerly winds, elevated relative humidity).

This vertical profile can be compared to the one observed the day before at the same location (3 July, flight V029 in Fig. $5 \mathrm{~b}$ ), when the ITD was located at around $15^{\circ} \mathrm{N}$. In this case the top height of the Monsoon layer $Z_{\mathrm{s}}$ was found at $1.6 \mathrm{~km}$, and dust was only observed in the SAL above $2 \mathrm{~km}$.

\subsection{Particle size distribution}

The normalised volume distributions $\mathrm{dV} / \mathrm{d} \log \mathrm{D}$ corresponding to vertical profiles discussed in the previous paragraphs are shown in Fig. 10.

All volume size distributions are characterised by a trimodal structure, which was modelled by multi-modal lognormal fitting. A first mode of particles of diameter smaller than $0.6 \mu \mathrm{m}$, not very well defined because of the lower size cut of the GRIMM OPC; a second mode of particles of diameter comprised between 0.6 and $2 \mu \mathrm{m}$ (modal median diameter $\sim 1 \mu \mathrm{m}$ ); and a third, dominant, above $2 \mu \mathrm{m}$ extending up to $20 \mu \mathrm{m}$ (modal median diameter between 3.8 and $7 \mu \mathrm{m}$ ). No systematic trend towards larger modal diameters is found depending on time after transport and origin.

The comparison of size distribution of mineral dust from one study to the other is a difficult task which depends also critically on the sampling method (Reid et al., 2003; Formenti et al., 2010). As a general remark, the analysis of airborne published results suggests that the SAMUM-based size 

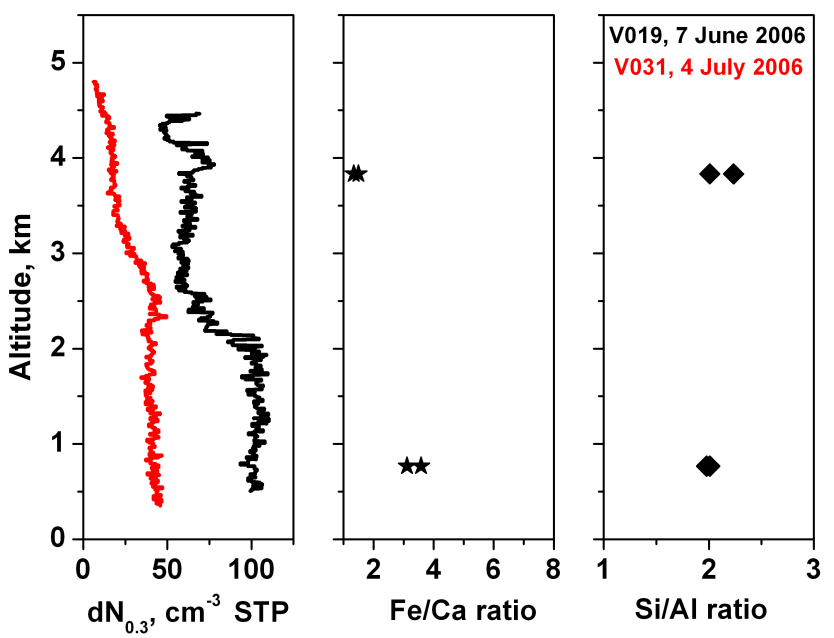

Fig. 9. Vertical profile of the $d N_{0.3}$ particle number concentrations at STP conditions (left panel), Fe/Ca elemental ratio (central panel) and $\mathrm{Si} / \mathrm{Al}$ elemental ratio (right panel) for the Saharan atmospheric boundary layer observed north of the ITD 7 June (flight V019). As term of comparison, the red line represents the $d N_{0.3}$ particle number concentrations at STP conditions for flight V031 conducted on 4 July north of Banizoumbou but south of the ITD. The elemental ratios are not available.

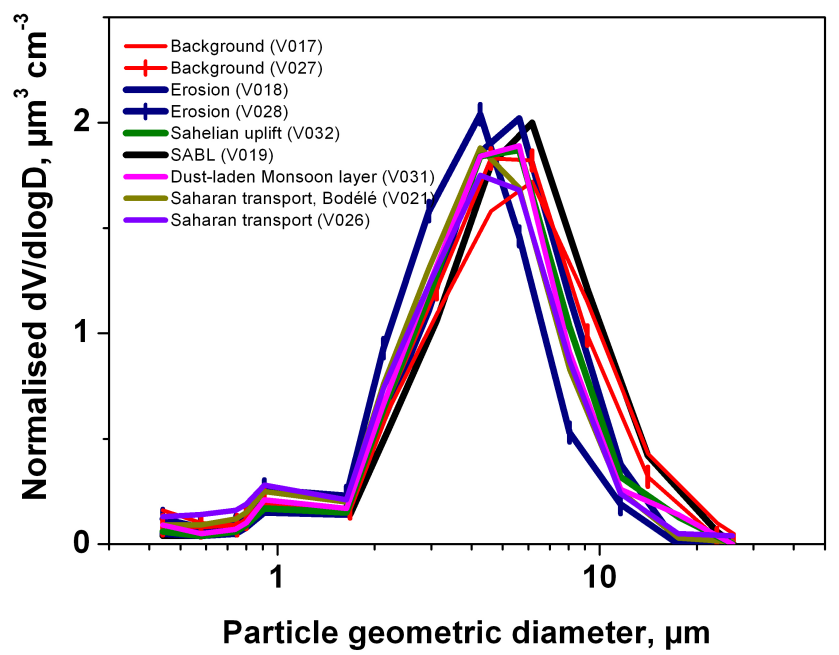

Fig. 10. Normalised mean volume size distributions for various case studies encountered during the field campaigns. Data correspond to straight and levelled runs at constant altitude.

distributions (Weinzierl et al., 2009) have a more pronounced coarse mode than those from the AMMA SOP-0/DABEX and DODO campaigns (Osborne et al., 2008; McConnell et al., 2008). Those from ground-based observations present the same kind of differences (e.g., Rajot et al., 2008; Kandler et al., 2009).
The analysis and the understanding of those differences are surely beyond the scope of this paper. Nonetheless, a simple comparison can be readily done with the observations of Rajot et al. (2008) during the wintertime period (AMMA SOP0) at the ground-based site of Banizoumbou. These authors also used a GRIMM OPC for their observations of mineral dust. They reported two prevailing values for the opticalequivalent modal median diameter of the particle volume distributions: $4.5 \mu \mathrm{m}$ for long-range advected dust transported to the site in the boundary layer and $8.7 \mu \mathrm{m}$ for dust emitted by local erosion. Assuming the same refractive index of the presently-discussed data, these modal diameter values correspond to 5 and $10 \mu \mathrm{m}$, respectively, when converted to geometric-equivalent values. The comparison shows that the position of modal median diameter is consistent between ground-based and airborne observations for advected dust. The airborne observations for the two erosion events detected during flight V018 and V028 report of a lower modal median diameter than those ground-based, 7 and $4 \mu \mathrm{m}$, respectively. Beside differences between the two episodes which could be attributed to below-cloud scavenging (see paragraph 4.3.3), it is likely that the underestimation of the airborne data can be attributed both to differential uplift above the surface level and to the fact that the airborne observation have been conducted at least $9-12 \mathrm{~h}$ after the erosive event. Even in the case when $10-\mu \mathrm{m}$ diameter particles had been uplifted at $0.5 \mathrm{~km}$, where the maximum extent of the dust layer was observed, assuming a deposition velocity of approximately $0.5 \mathrm{~cm} \mathrm{~s}^{-1}$ (Schmel, 1984), their concentrations would have been divided by a factor of two at the time of flight, which is consistent with the observations in Fig. 10.

\subsection{Optical properties}

The spectral single scattering albedo at seven wavelengths between 370 and $950 \mathrm{~nm}$ is shown in Fig. 11 for some of the dust case studies discussed in the previous paragraphs (postlocal erosion event, Sahelian dust uplift, SABL, Saharan dust transport). For those events, the scattering coefficients varied in the range $59-378 \mathrm{Mm}^{-1}$ at $370 \mathrm{~nm}$ and $41-366 \mathrm{Mm}^{-1}$ at $950 \mathrm{~nm}$. Values at wavelengths other than 450,550 and $700 \mathrm{~nm}$ were calculated by extrapolation using the spectral dependence obtained from the measurements. The range of variability of the measured absorption coefficients was 15$30 \mathrm{Mm}^{-1}$ at $370 \mathrm{~nm}$ and $3-5 \mathrm{Mm}^{-1}$ at $950 \mathrm{~nm}$.

The single scattering albedo ranged between 0.82-0.93 at $370 \mathrm{~nm}$ and between $0.91-0.99$ at $950 \mathrm{~nm}$. A formal error analysis, taking into account the experimental uncertainties on the scattering and absorption coefficients discussed in Sect. 2.3 and 2.4, allowed estimating the absolute error on the single scattering albedo to be \pm 0.01 . As shown in Fig. 11, differences in the relative magnitude of the single scattering albedo below $520 \mathrm{~nm}$ are therefore significant and results can be discussed with respect to the nature of the episodes (source region, transport time, physico-chemical properties). 


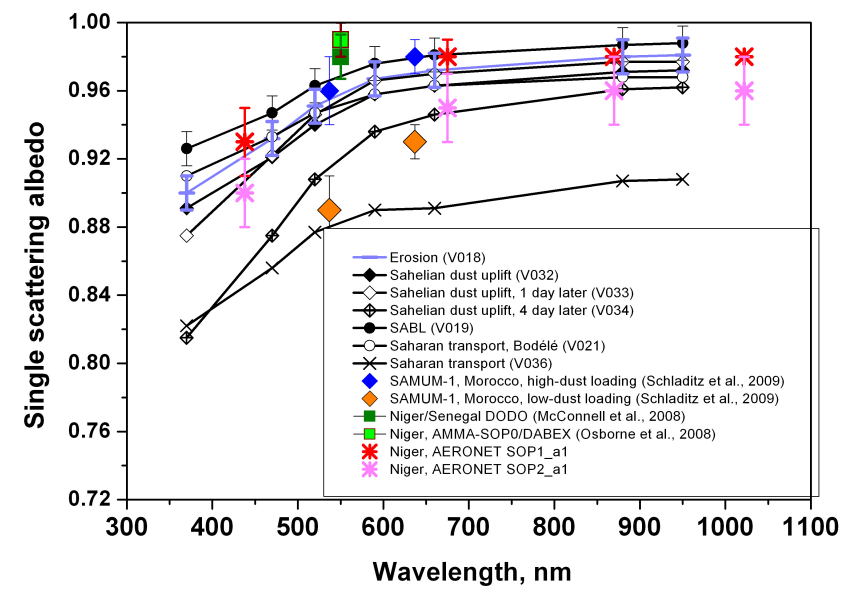

Fig. 11. Spectral single scattering albedo at seven wavelengths between 370 and $950 \mathrm{~nm}$ for various case studies of dust transport. Data correspond to straight and levelled runs performed within the dust layers of particular interest. Error bars on the in situ data represent the experimental error obtained from formal error analysis. For sake of clarity, there are shown on two data sets only (V018 and V019). For sake of comparison, data issued from the AMMA SOP0/DABEX (Osborne et al., 2008), the DODO (McConnell et al., 2008), the SAMUM 2006 (Schladitz et al., 2009) campaigns, as well as mean column-averaged values retrieved by the AERONET sunphotometer operated at the Banizoumbou station are also shown. Error bars on the AMMA SOP0/DABEX, DODO and SAMUM 2006 data correspond to the range of variability expressed in the publications from which the data are taken. Error bars of the AERONET data represent the standard deviation of the campaign mean.

The highest values, independently of the wavelengths, are observed for dust within the SABL. The lowest values are observed for Saharan dust transported within the SAL during flight V036, as well as for flight V034. In between are values for the Sahelian dust uplift cases (flights V032 and V033) for the erosion event encountered during flight V018.

The range of observed values is consistent with that reported by Redmond et al. (2010) who performed a synthesis of measurements from recent campaigns. For sake of comparison, Figure 11 also shows values issued from recent field campaigns (AMMA SOP0/DABEX, DODO and SAMUM1) and published by Osborne et al. (2008), McConnell et al. (2008) and Schladitz et al. (2009), respectively. Figure 11 also shows the mean and standard deviation of columnaveraged values retrieved during the SOP1 and SOP2_a1 periods by the AERONET sunphotometer which was operated at Banizoumbou.

It is worth noting that values in the mid-visible are lower than those reported by Osborne et al. (2008) for the single scattering albedo corresponding to accumulation-mode particle only for dust collected in the same region. This is consistent with the underestimation of particle absorption (in the absolute, but also in relative terms with comparison to scat- tering) because of the exclusion of the coarse mode. Same argument holds for McConnell et al. (2008), for the single scattering albedo observed over Mauritania and Senegal during the DODO campaigns.

The ground-based values reported by Schladitz et al. (2009) fall in two regimes, high-dust loading and lowdust-loading. The high-dust loading values fall in the upper range of our measurements, whereas the low-dust loading values are much lower and closer to the single scattering albedo observed during flights V034 and V036. The examination of the corresponding samples by electron microscopy indicated that the particle fraction smaller than $0.5 \mu \mathrm{m}$ in diameter mostly consisted of particles other than mineral dust, soot but also sulphates from biomass burning (not shown). These observations are consistent with most of the in situ observations which had been conducted in the Western Africa atmosphere both in the dry and the summertime seasons (Chou et al., 2008; Müller et al., 2009; Schladitz et al., 2009; Kandler et al., 2009), and in particular with those by Matsuki et al. (2010) in the Niamey-Banizoumbou area later in the wet season. As also observed by Schladitz et al. (2009), the optical effect of these absorbing particles is surely more evident when the total particle concentration is lower than for the other cases.

To understand these effects, Mie-calculations of the measured scattering and absorption coefficients were performed based on the measured number size distributions. These were used to estimate the spectral single scattering albedo, and so understand the relative contribution of particle size and composition in determining the dust optical properties. The number fraction of particles smaller than $0.3 \mu \mathrm{m}$ was accounted for by performing log-normal fitting of the measured size distribution. This way of estimating the magnitude of the accumulation mode is of course not very well constrained because the first particle size bin of the GRIMM optical counter is already on the decreasing slope of the particle accumulation mode. However, sensitivity tests performed by varying the height of this fine mode demonstrated that less than $10 \%$ of light extinction is due to particles smaller than $0.3 \mu \mathrm{m}$ in diameter, and that the calculation of scattering and absorption are influenced in equal way. As a consequence, there is little influence of particles smaller than $0.3 \mu \mathrm{m}$ on the calculated single scattering albedo.

The complex refractive index has been left as free parameter and fixed when the difference between the measurement and the calculation was within $5 \%$. The real part of the refractive index was fixed to 1.53 which is in accordance with Osborne et al. (2008), Müller et al. (2009), Schladitz et al. (2009) and in the mid-range of values obtained by Petzold et al. (2009) and Klaver et al. (2011). The imaginary part was varied between 0.002 and 0.008 at $370 \mathrm{~nm}$ and between 0.001 and 0.004 at $950 \mathrm{~nm}$, again in the range indicated by the latest observations in Western and Northern Africa (Osborne et al., 2008; McConnell et al., 2008; 2010; Müller et al., 2009; Kandler et al., 2009; Petzold et al., 2009; Schladitz 
Table 4. Spectrally-resolved imaginary part of the complex refractive index obtained as a closure parameter between the measured single scattering albedo and the Mie calculation using measured number size distributions for a number of case studies of dust of different origin and residence time.

\begin{tabular}{llllllll}
\hline & 370 & 470 & 520 & 590 & 660 & 880 & 950 \\
\hline SABL (V019), 0.7 km a.s.l. & 0.002 & 0.001 & 0.001 & 0.001 & 0.001 & 0.001 & 0.001 \\
Saharan transport, Bodélé (V021), 0.7 km a.s.l. & 0.004 & 0.003 & 0.002 & 0.002 & 0.002 & 0.002 & 0.002 \\
Erosion (V018), 0.7 km a.s.l. & 0.003 & 0.002 & 0.002 & 0.001 & 0.001 & 0.001 & 0.001 \\
Sahelian uplift (V032), 1.7 km a.s.l. & 0.003 & 0.002 & 0.002 & 0.001 & 0.001 & 0.001 & 0.001 \\
Sahelian uplift (V033), 2.7 mm a.s.l. & 0.004 & 0.002 & 0.002 & 0.001 & 0.001 & 0.001 & 0.001 \\
Sahelian uplift (V034), 2.3 km a.s.l. & 0.008 & 0.007 & 0.005 & 0.003 & 0.003 & 0.002 & 0.002 \\
Saharan transport (V036), 2.5 km a.s.l. & 0.008 & 0.006 & 0.005 & 0.005 & 0.005 & 0.004 & 0.004 \\
\hline
\end{tabular}

Table 5. Spectrally-resolved asymmetry factor calculated using the estimated complex refractive indices (real part $=1.53$; imaginary part $=$ see Table 5) by Mie calculation using measured number size distributions for a number of case studies of dust of different origin and residence time.

\begin{tabular}{lccccccc}
\hline & 370 & 470 & 520 & 590 & 660 & 880 & 950 \\
\hline SABL (V019), 0.7 km a.s.l. & 0.77 & 0.74 & 0.75 & 0.73 & 0.73 & 0.71 & 0.71 \\
Saharan transport, Bodélé (V021), 0.7 km a.s.1. & 0.76 & 0.74 & 0.73 & 0.72 & 0.72 & 0.69 & 0.69 \\
Erosion (V018), 0.7 km a.s.1. & 0.78 & 0.75 & 0.75 & 0.73 & 0.73 & 0.70 & 0.70 \\
Sahelian uplift (V032), 1.7 km a.s.l. & 0.77 & 0.75 & 0.75 & 0.73 & 0.73 & 0.70 & 0.70 \\
Sahelian uplift (V033), 2.7 mm a.s.l. & 0.77 & 0.74 & 0.75 & 0.73 & 0.72 & 0.69 & 0.70 \\
Sahelian uplift (V034), 2.3 km a.s.l. & 0.77 & 0.75 & 0.74 & 0.72 & 0.71 & 0.68 & 0.68 \\
Saharan transport (V036), 2.5 km a.s.l. & 0.75 & 0.74 & 0.73 & 0.72 & 0.71 & 0.68 & 0.68 \\
\hline
\end{tabular}

et al., 2009). Results of the closure experiments shown in Table 4 are consistent with the above-mentioned literature. Note, however, that Osborne et al. (2008) and McConnell et al. (2008) report an imaginary lower by an order of magnitude with respect to our measurements, possibly as a consequence of the fact that they mostly probed the accumulation mode fraction. The highest values of the imaginary part were found for the same flights for which the single scattering albedo is lower (V034 and V036), confirming that the composition of the aerosol encountered during those flights should be significantly different from that encountered in the other cases. This is consistent with the presence of soot in the particle fraction below $0.5 \mu \mathrm{m}$.

Finally, the measured number size distribution and calculated refractive index obtained by optical closure were used to estimate the asymmetry factor at the seven wavelengths (Table 5). Values range between 0.75 and 0.78 at $370 \mathrm{~nm}$ and between 0.68 and 0.71 at $950 \mathrm{~nm}$. Values at $520 \mathrm{~nm}$ are in the $0.73-0.75$, in agreement with previous investigations (Haywood et al., 2003a; Osborne et al., 2008; McConnell et al., 2008). There is no straightforward dependence on the origin of dust.

\section{Discussion and conclusions}

In this paper we have presented data on concentrations, composition, size distribution and optical properties of mineral dust of Saharan and Sahelian origin observed during the first two summertime intensive field phases of the AMMA program in June-July 2006.

Flights during these intensive research periods illustrated the variability of the dust distribution and vertical profile depending on meteorological conditions and residence time after emission. Dust was ubiquitous north of $12^{\circ} \mathrm{N}$. South of $12^{\circ} \mathrm{N}$, intense aerosol plumes were observed over the coastal city of Cotonou and at approximately $2^{\circ} \mathrm{N}$ in correspondence of the advection of a biomass burning plume from the Southern Hemisphere.

Surface transport is the common transport pathway in wintertime (Chiapello et al., 1995; Rajot et al., 2008; Heese and Wiegner, 2008; Osborne et al., 2008) but in summertime it was only observed during a few hours after a local erosion episode. Transport in the free troposphere was observed in single or multiple sub-layers, depending on time after emission. Generally, multi-plume layering was observed following turbulent uplifting. The lowermost extent of the dust plumes above the boundary layer varies between 1.5 and $2 \mathrm{~km}$, whereas the uppermost extent was found to be remarkably constant at $5 \mathrm{~km}$. The vertical extent, but also the structural and temporal variability of the dust vertical profiles is in 
agreement with summertime observations by various authors (Prospero and Carlson, 1972; Carlson and Prospero, 1972; Karyampudi et al., 1999; Formenti et al., 2003; Reid et al., 2002; McConnell et al., 2008; Tesche et al., 2009; Léon et al., 2009; Ben-Ami et al., 2009; Cavalieri et al., 2010). In particular, our data show the day-to-day variability of the dust vertical profile, in good agreement, albeit with lower statistical representation, with the long-time series of lidar data presented by Léon et al. (2009) and Cavalieri et al. (2010). Sub-daily scale variability related to the development of thermal turbulence or the perturbation by convective systems is also likely to be relevant but it is beyond the scope of this paper.

Dust layers of differing origin were identified on the basis of the meteorological record of occurrence of MSCs and by the examination of the simple inter-elemental ratios between major dust tracers, i.e., $\mathrm{Al}, \mathrm{Si}, \mathrm{Ca}$ and $\mathrm{Fe}$.

Various types of situations were encountered: (1) enhanced dust concentrations in the boundary layer below 1$1.5 \mathrm{~km}$ corresponding to local erosion; (2) enhanced dust concentrations in the boundary layer this time extending up to $3 \mathrm{~km}$ and corresponding to the dust laden Saharan atmosphere north of the ITD; (3) enhanced single-layer dust concentrations in the free troposphere between 1.5 and $5 \mathrm{~km}$ corresponding to the dust transport in the Saharan Air layer (SAL); and (4) single and multi-layers in the free troposphere between 1.5 and $5 \mathrm{~km}$ corresponding to the dust transport from the Bodélé depression or to the turbulent uplift of Sahelian dust. Surface local erosion and Bodélé dust were characterised by elevated $\mathrm{Si} / \mathrm{Al}$ ratios ( $\mathrm{Si} / \mathrm{Al}$ of the order of $3-4$ ) due, in the first case, to the injection of large quartz particles, and in the second case, to the presence of diatomite debris. Conversely, the $\mathrm{Si} / \mathrm{Al}$ ratio for Sahelian dust in the free troposphere is lower than 2, suggesting that large quartz grain are not significantly uplifted after emission. Both at the surface and in the free troposphere, Sahelian dust is also characterised by mean Fe/Ca ratios higher than 4 . This is due both to the enhancement of the iron content and to the depletion of the calcium content, linked to the Sahelian soil mineral mineralogy (Claquin et al., 1999; Kandler et al., 2007; Formenti et al., 2008). The quantification of the oxide fraction in iron was possible on a few samples only collected during the erosion event of flight V028 and on the SABL layer north of the ITD and revealed values comparable with very recent observations that our research group has performed for Sahelian and Saharan dust (Lafon et al., 2004; Formenti et al., 2008; Klaver et al., 2011). We have indicated a certain spread in the estimate of the percent fraction of iron oxides in our samples owing to the lack of a direct measurement of the total dust mass. Nonetheless, the percent fraction of iron oxide in dust is of the order of $3 \%$ when estimating the total dust mass as proportional to elemental Al. Klaver et al. (2011) has recently demonstrated that this assumption allows approximating very well the gravimetric mass of Saharan and Sahelian aerosols.
The vertical profile of the elemental composition illustrates the positive answer to one of the major questions that had motivated the research activities on mineral dust within AMMA, i.e., whether dust emitted by wind-erosion by MCS over Sahelian soils could have been uplifted to the SAL where the AEJ would favour long-range transport towards the Atlantic ocean. The export of Sahelian dust could have implication for the estimation of the direct radiative effect at the global scale as well as for ocean and soil fertilisation (Jickells et al., 2005; Balkanski et al., 2007). Our data indicate that only one episode (6-10 July) of Sahelian dust uplift and mixing within the SAL occurred during the AMMA SOP1 and SOP2_a1 field phases, suggesting that the summertime export of Sahelian dust might be minor with respect to the outflow of Saharan dust, which is also more persistent through the year. Not forgetting that this frequency might be under-sampled due to difficulties in flying soon after the occurrence of the MCSs, our results are in agreement with the conclusions from Desboeufs et al. (2010) based on the chemical characterisation of rain events during the monsoon period. The role of the precipitating event surely also conditions the Sahelian dust transport in the SAL in scavenging dust uplift. The occasional frequency of Sahelian transport at the continental scale is also suggested by individual particle analysis of Reid et al. (2003) on samples of transported dust collected in the Caribbean.

The analysis of the volume size distribution of dust of different origin does not seem to depend on the source region but rather on the residence time in the atmosphere. This is in accordance with the surface observations by Rajot et al. (2008) in the wintertime. On the contrary, Reid et al. (2008) suggested that dust of different origin has initially different size distributions, which become indistinguishable after two days of transport in the atmosphere. The ensemble of these observations is not necessarily in conflict. We, as Rajot et al. (2008), mostly sampled dust freshly emitted or within 1-2 days of transport. The similarity of the size distribution of local emitted dust at the surface during 6 June (V018) to that of Sahelian dust at about $2 \mathrm{~km}$ on 6 July (V032) might not being significant as the area where emission had happened is not the same but nonetheless close (within the Sahel). In this sense, these observations are not able to show a possible dependence on source region. More measurements of the size distribution of the vertical flux at emission, like those performed in Banizoumbou by Sow et al. (2009) are needed to investigate this point, in comparison to the modelling results of Alfaro and Gomes (2001). The evolution of the size distribution during the episode of transport of Sahelian dust tends to confirm the conclusion of Reid et al. (2008) concerning the relative invariance with time after 1-2 days of transport. Nonetheless, size distribution measurements in this work as well in the work of Reid et al. (2008) were performed behind an inlet with a $50 \%$ cut-off at or below $10 \mu \mathrm{m}$. A larger variation in particle concentration could be expected particularly for larger 
particles (e.g., d'Almeida and Schütz, 1983; Kandler et al., 2009).

We also present the first measurements of the single scattering albedo of Sahelian dust. Our estimates are in good agreement with previous in situ observations for African dust when the particle coarse mode is taken into account (summarized by Redmond et al., 2010). Beside the cases of dust transport in the SAL, whose absorption properties might be biased towards low values due to mixing with pollution aerosol, it is demonstrated that at wavelengths smaller than $500 \mathrm{~nm}$ Sahelian dust has lower single scattering albedo values than Saharan dust found north of the ITD, although the iron oxide content is rather the same. Klaver et al. (2011) have demonstrated that the single scattering albedo cannot be parameterised linearly by the iron oxide content but the full mineralogical composition is necessary to estimate the spectral variability of the complex refractive index, and by consequence of the single scattering albedo of mineral dust.

The significance of the differences in the estimated optical properties (single scattering albedo and asymmetry factor) needs to be evaluated with respect to the implication for the dust radiative effect. In our data, the measured single scattering albedo at $500 \mathrm{~nm}$ is 0.94 and 0.96 for Sahelian and Saharan dust, respectively. A simple calculation indicates that over bare surfaces with surface albedo larger than 0.5, both Sahelian and Saharan dust will warm the atmospheric column (positive forcing at the top of the atmosphere). The warming effect will be moderate but twice as high for Sahelian than for Saharan dust. This case is relevant also in the case when mineral dust is transported over clouds, as it is frequent, especially as soon as the dust plumes leave the African continent. For lower surface albedos, both Sahelian and Saharan dust will cool the atmospheric column. In this case, the cooling effect will be higher for Saharan dust but will tend to equality over dark surfaces such as the ocean. Despite the relative infrequency of the long-range transport of Sahelian dust, the implication of such differences on the redistribution of energy within the atmospheric column, on the convective stability and on the cloud cover of mineral dust needs to be further evaluated. Mesoscale modelling should be pursued to address these issues.

Acknowledgements. Based on a French initiative, AMMA was built by an international scientific group and is currently funded by a large number of agencies, especially from France, the United Kingdom, the United States, and Africa. It has been the beneficiary of a major financial contribution from the European Community's Sixth Framework Research Programme. Detailed information on scientific coordination and funding is available on the AMMA International Web site at www.amma-international.org.

We thank Didier Tanré (Laboratoire Optique Atmosphérique, Lille) and Bernadette Chatenet (LISA) for theirs effort in establishing and maintaining the Banizoumbou, Cinzana, and Djougou sites.

The authors wish to thank the personnel of the Division Technique of the CNRS/INSU (DT-INSU) for supporting the technical development of the AVIRAD sampling system. F. Baudin, former director of this unit, is particularly acknowledged. The instrument scientists, pilots and ground crew of SAFIRE are thanked for facilitating the instrument integration and conducting flying operations. A. Gaudichet is thanked for support to the experimental field phases.

Edited by: A. Petzold

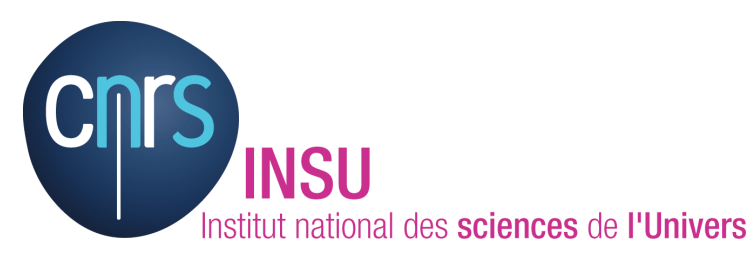

The publication of this article is financed by CNRS-INSU.

\section{References}

Abdourhamane Touré, A., Rajot, J. L., Garba, Z., Marticorena, B., Petit, C., and Sebag, D.: Impact of very low crop residues cover on wind erosion in the Sahel, Catena, 85, 205-214, 2011.

Alfaro, S. C. and Gomes, L.: Modeling mineral aerosol production by wind erosion: Emission intensities and aerosol size distributions in source areas, J. Geophys. Res., 106, 18075-18084, doi:10.1029/2000jd900339, 2001.

Alfaro, S. C., Lafon, S., Rajot, J. L., Formenti, P., Gaudichet, A., and Maillé, M.: Iron oxides and light absorption by pure desert dust: An experimental study, J. Geophys. Res., 109, D08208, doi:10.1029/2003jd004374, 2004.

d'Almeida, G. A. and Schütz, L.: Number, mass and volume distributions of mineral aerosol and soils of the Sahara. J. Clim. Appl. Meteorol. 22, 233-243, 1983.

Anderson, T. L., Covert, D. S., Marshall, S. F., Laucks, M. L., Charlson, R. J., Waggoner, A. P., Ogren, J. A., Caldow, R., Holm, R. L., Quant, F. R., Sem, G. J., Wiedensholer, A., Ahlquist, N. A., and Bates, T. S.: Performance characteristics of a high-sensitivity, three-wavelength, total scatter/backscatter nephelometer, J. Atmos. Ocean. Tech., 13, 967-986, 1996.

Balkanski, Y., Schulz, M., Claquin, T., and Guibert, S.: Reevaluation of Mineral aerosol radiative forcings suggests a better agreement with satellite and AERONET data, Atmos. Chem. Phys., 7, 81-95, doi:10.5194/acp-7-81-2007, 2007.

Ben-Ami, Y., Koren, I., and Altaratz, O.: Patterns of North African dust transport over the Atlantic: winter vs. summer, based on CALIPSO first year data, Atmos. Chem. Phys., 9, 7867-7875, doi:10.5194/acp-9-7867-2009, 2009.

Bristow, C. S., Hudson-Edwards, K. A., and Chappell, A.: Fertilizing the Amazon and equatorial Atlantic with West African dust, Geophys. Res. Lett., 37, L14807, doi:10.1029/2010g1043486, 2010.

Canut G., Lothon, M., Saïd, F., and Lohou, F.: Small scale interaction between monsoon and Saharan Air Layer, Q. J. Roy. Meteorol. Soc. 136(s1), 34-46, doi:10.1002/qj.471, 2010.

Caquineau, S.: Les sources des aérosols sahariens transportés au dessus de l'Atlantique tropical Nord: Localisation et car- 
actéristiques minéralogiques, Ph.D. thesis, Univ. Paris 12, Valde-Marne, France, 181 pp., 1997.

Caquineau, S., Gaudichet, A., Gomes, L., and Legrand, M.: Mineralogy of Saharan dust transported over northwestern tropical Atlantic Ocean in relation to source regions, J. Geophys. Res., 107, 4251, doi:10.1029/2000jd000247, 2002.

Carlson, T. N. and Prospero, J. M.: The large-scale movement of Saharan air outbreaks over the northern Equatorial Atlantic., J. Appl. Meteor., 11, 283-297, 1972.

Cavalieri, O., Cairo, F., Fierli, F., Di Donfrancesco, G., Snels, M., Viterbini, M., Cardillo, F., Chatenet, B., Formenti, P., Marticorena, B., and Rajot, J. L.: Variability of aerosol vertical distribution in the Sahel, Atmos. Chem. Phys., 10, 12005-12023, doi:10.5194/acp-10-12005-2010, 2010.

Chiapello, I., Bergametti, G., Gomes, L., Chatenet, B., Dulac, F., Pimenta, J., and Santos Suares, E.: An additional low layer transport of Sahelian and Saharan dust over the north-eastern tropical Atlantic, Geophys. Res. Lett., 22, 3191-3194, 1995.

Chiapello, I., Bergametti, G., Chatenet, B., Bousquet, P., Dulac, F., and Santos Suares, E.: Origins of African dust transported over the northeastern tropical Atlantic, J. Geophys. Res., 102, 1370113709, 1997.

Chou, C., Formenti, P., Maille, M., Ausset, P., Helas, G., Harrison, M., and Osborne, S.: Size distribution, shape, and composition of mineral dust aerosols collected during the African Monsoon Multidisciplinary Analysis Special Observation Period 0: Dust and Biomass-Burning Experiment field campaign in Niger, January 2006, J. Geophys. Res., 113, D00C10, doi:10.1029/2008jd009897, 2008.

Claquin, T., Schulz, M., and Balkanski, Y. J.: Modeling the mineralogy of atmospheric dust sources, J. Geophys. Res., 104, $22243-$ 22256, 1999.

Collaud Coen, M., Weingartner, E., Apituley, A., Ceburnis, D., Fierz-Schmidhauser, R., Flentje, H., Henzing, J. S., Jennings, S. G., Moerman, M., Petzold, A., Schmid, O., and Baltensperger, U.: Minimizing light absorption measurement artifacts of the Aethalometer: evaluation of five correction algorithms, Atmos. Meas. Tech., 3, 457-474, doi:10.5194/amt-3-457-2010, 2010.

Collins, D. R., Johnsson, H. H., Seinfeld, J. H., Flagan, R. C., Gassó, S., Hegg, D. A., Russell, P. B., Schmid, B., Livingston, J. M., Öström, E., Noone, K. J., Russell, L. M., and Putaud, J. P.: In situ aerosol size distributions and clear column radiative closure during ACE-2, Tellus, 52B, 498-525, 2000.

Cuesta, J., Edouart, D., Mimouni, M., Flamant, P. H., Loth, C., Gibert, F., Marnas, F., Bouklila, A., Kharef, M., Ouchène, B., Kadi, M., and Flamant, C.: Multiplatform observations of the seasonal evolution of the Saharan atmospheric boundary layer in Tamanrasset, Algeria, in the framework of the African Monsoon Multidisciplinary Analysis field campaign conducted in 2006, J. Geophys. Res., 113, D00C07, doi:10.1029/2007jd009417, 2008.

Delmas, R., Megie, G., Peuch, V. H., et al.: Physique et Chimie de l'Atmosphre, Editions Belin, Collection Echelles, 650 pp., 2005.

DeMott, P. J., Sassen, K., Poellot, M. R., Baumgardner, D., Rogers, D. C., Brooks, S. D., Prenni, A. J., and Kreidenweis, S. M.: African dust aerosols as atmospheric ice nuclei, Geophys. Res. Lett., 30, 1732, doi:10.1029/2003gl017410, 2003.

Desboeufs, K., Journet, E., Rajot, J. L., Chevaillier, S., Triquet, S., Formenti, P., and Zakou, A.: Chemistry of rain events in West Africa: evidence of dust and biogenic influence in convective systems, Atmos. Chem. Phys., 10, 9283-9293, doi:10.5194/acp10-9283-2010, 2010.

Fiedler, V., Arnold, F., Ludmann, S., Minikin, A., Hamburger, T., Pirjola, L., Dörnbrack, A., and Schlager, H.: African biomass burning plumes over the Atlantic: aircraft based measurements and implications for $\mathrm{H}_{2} \mathrm{SO}_{4}$ and $\mathrm{HNO} 3$ mediated smoke particle activation, Atmos. Chem. Phys., 11, 3211-3225, doi:10.5194/acp-11-3211-2011, 2011.

Flamant, C., Lavaysse, C., Todd, M. C., Chaboureau, J. P., and Pelon, J.: Multi-platform observations of a springtime case of Bodélé and Sudan dust emission, transport and scavenging over West Africa, Q. J. Roy. Meteorol. Soc., 135, 413-430, doi:10.1002/qj.376, 2009.

Formenti, P., Reiner, T., Sprung, D., Andreae, M. O., Wendisch, M., Wex, H., Kindred, D., Dewey, K., Kent, J., Tzortziou, M., Vasaras, A., and Zerefos, C.: STAAARTE-MED 1998 summer airborne measurements over the Aegean Sea 1. Aerosol particles and trace gases, J. Geophys. Res., 107, 4550, doi:10.1029/2001jd001337, 2002.

Formenti, P., Elbert, W., Maenhaut, W., Haywood, J., and Andreae, M. O.: Chemical composition of mineral dust aerosol during the Saharan Dust Experiment (SHADE) airborne campaign in the Cape Verde region, September 2000, J. Geophys. Res., 108, 8576, doi:10.1029/2002jd002648, 2003.

Formenti, P., Rajot, J. L., Desboeufs, K., Caquineau, S., Chevaillier, S., Nava, S., Gaudichet, A., Journet, E., Triquet, S., Alfaro, S., Chiari, M., Haywood, J., Coe, H., and Highwood, E.: Regional variability of the composition of mineral dust from western Africa: Results from the AMMA SOP0/DABEX and DODO field campaigns, J. Geophys. Res., 113, D00C13, doi:10.1029/2008jd009903, 2008.

Formenti, P., Schuetz, L., Balkanski, Y., Desboeufs, K., Ebert, M., Kandler, K., Petzold, A., Scheuvens, D., Weinbruch, S., and Zhang, D.: Recent progress in understanding physical and chemical properties of mineral dust, Atmos. Chem. Phys. Discuss., 10, 31187-31251, doi:10.5194/acpd-10-31187-2010, 2010.

Formenti, P., N. Grand, R. Caillou, P. Nacass, M. Maillé, R. Loisil, S. Letourneur, C. Berthod, R. Entringer, A. Clemencon, D. Chaize, D. Filippi, J.-C. Le Roulley, D. Basbayou and G. Kos, The AVIRAD aerosol airborne sampling system: design and validation, Atmos. Meas. Tech., to be submitted, 2011.

Forster, P., V. Ramaswamy, P. Artaxo, T. Berntsen, R. Betts, D.W. Fahey, J. Haywood, J. Lean, D.C. Lowe, G. Myhre, J. Nganga, R. Prinn, G. Raga, Schulz, M., and R. Van Dorland: Changes in Atmospheric Constituents and in Radiative Forcing, Cambridge University Press, Cambridge, UK and New York, NY, USA, 2007.

Goudie, A. S. and Middleton, N. J.: Saharan dust storms: nature and consequences, Earth-Sci. Rev., 56, 179-204, 2001.

Greenland, D. J., Oades, J. M., and Sherwin, T. W.: Electron microscope observations of iron oxides in some red soils, J. Soil Sci., 123-126, 1968.

Haywood, J., Francis, P., Osborne, S., Glew, M., Loeb, N., Highwood, E., Tanré, D., Myhre, G., Formenti, P., and Hirst, E.: Radiative properties and direct radiative effect of Saharan dust measured by the C-130 aircraft during SHADE: 1. Solar spectrum, J Geophys. Res., 108, 8577, doi:10.1029/2002jd002687, $2003 \mathrm{a}$.

Haywood, J. M., Osborne, S. R., Francis, P. N., Keil, A., Formenti, P., Andreae, M. O., and Kaye, P. H.: The mean physical and 
optical properties of regional haze dominated by biomass burning aerosol measured from the C-130 aircraft during SAFARI 2000, J. Geophys. Res., 108, 8473, doi:10.1029/2002jd002226, 2003b.

Heese, B. and Wiegner, M.: Vertical aerosol profiles from Raman polarization lidar observations during the dry season AMMA field campaign, J. Geophys. Res., 113, D00C11, doi:10.1029/2007jd009487, 2008.

Holben, B. N., Eck, T. F., Sluster, I., Tanré, D., Buis, J. P., Setzer, A., Vermote, E., Reagan, J. A., Kaufman, Y. J., Nakajima, T., Lavenu, F., Jankowiak, I., and Smirnov, Z.: AERONET-A federated instrument network and data archive for aerosol characterisation, Rem. Sens. Environ., 66, 1-16, 1998.

Holben, B. N., Tanré, D., Smirnov, A., Eck, T. F., Slutsker, I., Abuhassan, N., Newcomb, W. W., Schafer, J. S., Chatenet, B., Lavenu, F., Kaufman, Y. J., Castle, J. V., Setzer, A., Markham, B., Clark, D., Frouin, R., Halthore, R., Karneli, A., O'Neill, N. T., Pietras, C., Pinker, R. T., Voss, K., and Zibordi, G.: An emerging ground-based aerosol climatology: Aerosol optical depth from AERONET, J. Geophys. Res., 106, 12067-12097, doi:10.1029/2001jd900014, 2001.

Janicot, S., Thorncroft, C. D., Ali, A., Asencio, N., Berry, G., Bock, O., Bourles, B., Caniaux, G., Chauvin, F., Deme, A., Kergoat, L., Lafore, J. P., Lavaysse, C., Lebel, T., Marticorena, B., Mounier, F., Nedelec, P., Redelsperger, J. L., Ravegnani, F., Reeves, C. E., Roca, R., de Rosnay, P., Schlager, H., Sultan, B., Tomasini, M., Ulanovsky, A., and team, A. f.: Large-scale overview of the summer monsoon over West Africa during the AMMA field experiment in 2006, Ann. Geophys., 26, 25692595, doi:10.5194/angeo-26-2569-2008, 2008.

Jickells, T. D., An, Z. S., Andersen, K. K., Baker, A. R., Bergametti, G., Brooks, N., Cao, J. J., Boyd, P. W., Duce, R. A., Hunter, K. A., Kawahata, H., Kubilay, N., laRoche, J., Liss, P. S., Mahowald, N., Prospero, J. M., Ridgwell, A. J., Tegen, I., and Torres, R.: Global Iron Connections Between Desert Dust, Ocean Biogeochemistry, and Climate, Science, 308, 6771, 10.1126/science.1105959, 2005.

Johnson, B. T., Osborne, S. R., Haywood, J. M., and Harrison, M. A. J.: Aircraft measurements of biomass burning aerosol over West Africa during DABEX, J. Geophys. Res., 113, D00C06, doi:10.1029/2007jd009451, 2008.

Kalapureddy M. C. R., Lothon, M., Campistron, B., Lohou, F., and Saïd, F.: Wind profiler analysis of the African Easterly Jet in relation with the boundary-layer and the Saharan Heat Low, Q. J. Roy. Meteorol. Soc., 136(S1), 77-91, doi:10.1002/qj.494, 2010.

Kalu, A. E.: The African Dust Plume: Its Characteristics and Propagation Across West Africa in Winter, in: SCOPE 14: Saharan Dust Mobilization, Transport, Deposition, John Wiley \& Sons, New York, USA, 96-118, 1979.

Kandler, K., Benker, N., Bundke, U., Cuevas, E., Ebert, M., Knippertz, P., Rodriguez, S., Schütz, L., and Weinbruch, S.: Chemical composition and complex refractive index of Saharan mineral dust at Izana, Tenerife (Spain) derived by electron microscopy, Atmos. Environ., 41, 8058-8074, 2007.

Kandler, K. and Schütz, L.: Climatology of the average watersoluble volume fraction of atmospheric aerosol, Atmos. Res., 83, 77-92, 2007.

Kandler, K., Schütz, L., Deutscher, C., Ebert, M., Hofmann, H., Jäckel, S., Jaenicke, R., Knippertz, P., Lieke, K., Massling, A., Petzold, A., Schladitz, A., Weinzierl, B., Wiedensohler, A., Zorn,
S., and Weinbruch, S.: Size distribution, mass concentration, chemical and mineralogical composition and derived optical parameters of the boundary layer aerosol at Tinfou, Morocco, during SAMUM 2006, Tellus B, 61, 32-50, doi:10.1111/j.16000889.2008.00385.x, 2009.

Karickhoff, S. W. and Bailey, G. W.: Optical absorption spectra of clay minerals, Clays Clay Min., 21, 59-70, 1973.

Karyampudi, V. M., Palm, S. P., Reagen, J. A., Fang, H., Grant, W. B., Hoff, R. M., Moulin, C., Pierce, H. F., Torres, O., Browell, E. V., and Melfi, S. H.: Validation of the Saharan dust plume conceptual model using lidar, Meteosat, and ECMWF data., B. Am. Meteorol. Soc., 80, 1045-1075, 1999.

Kim, S. W., Chazette, P., Dulac, F., Sanak, J., Johnson, B., and Yoon, S. C.: Vertical structure of aerosols and water vapor over West Africa during the African monsoon dry season, Atmos. Chem. Phys., 9, 8017-8038, doi:10.5194/acp-9-8017-2009, 2009.

Klaver, A., Formenti, P., Caquineau, S., Chevaillier, S., Ausset, P., Nava, S., Osborne, S., Johnson, B., Harrison, M., and Dubovik, O.: Measurements and modeling of the single scattering albedo of Sahelian mineral dust from in situ measurements of the physico-chemical properties: results from the GERBILS campaign, Q. J. Roy. Meteorol. Soc., in press, 2011.

Koehler, K. A., Kreidenweis, S. M., DeMott, P. J., Petters, M. D., Prenni, A. J., and Carrico, C. M.: Hygroscopicity and cloud droplet activation of mineral dust aerosol, Geophys. Res. Lett., 36, L08805, doi:10.1029/2009g1037348, 2009.

Lafon, S., Rajot, J., Alfaro, S., and Gaudichet, A.: Quantification of iron oxides in desert aerosol., Atmos. Environ., 38, 1211-1218, 2004.

Lafon, S., Sokolik, I. N., Rajot, J. L., Caquineau, S., and Gaudichet, A.: Characterization of iron oxides in mineral dust aerosols: Implications for light absorption, J. Geophys. Res., 111, D21207, doi:10.1029/2005jd007016, 2006.

Laurent, B., Marticorena, B., Bergametti, G., Léon, J. F., and Mahowald, N. M.: Modeling mineral dust emissions from the Sahara desert using new surface properties and soil database, J. Geophys. Res., 113, D14218, doi:10.1029/2007jd009484, 2008.

Lebel, T., Parker, D. J., Flamant, C., Bourlès, B., Marticorena, B., Mougin, E., Peugeot, C., Diedhiou, A., Haywood, J. M., Ngamini, J. B., Polcher, J., Redelsperger, J. L., and Thorncroft, C. D.: The AMMA field campaigns: multiscale and multidisciplinary observations in the West African region, Q. J. Roy. Meteorol. Soc., 136, 8-33, doi:10.1002/qj.486, 2010.

Léon, J. F., Derimian, Y., Chiapello, I., Tanré, D., Podvin, T., Chatenet, B., Diallo, A., and Deroo, C.: Aerosol vertical distribution and optical properties over M'Bour $\left(16.96^{\circ} \mathrm{W} ; 14.39^{\circ} \mathrm{N}\right)$, Senegal from 2006 to 2008, Atmos. Chem. Phys., 9, 9249-9261, doi:10.5194/acp-9-9249-2009, 2009.

Liu, Y. and Daum, P.: The effect of refractive index on size distributions and light scattering coefficients derived from optical particle counters, J. Aerosol Sci., 31, 945-957, 2000.

Mari, C. H., Cailley, G., Corre, L., Saunois, M., Attié, J. L., Thouret, V., and Stohl, A.: Tracing biomass burning plumes from the Southern Hemisphere during the AMMA 2006 wet season experiment, Atmos. Chem. Phys., 8, 3951-3961, doi:10.5194/acp-8-3951-2008, 2008.

Marticorena, B., Chatenet, B., Rajot, J. L., Traoré, S., Coulibaly, M., Diallo, A., Koné, I., Maman, A., Ndiaye, T., and Zakou, A.: 
Temporal variability of mineral dust concentrations over West Africa: analyses of a pluriannual monitoring from the AMMA Sahelian Dust Transect, Atmos. Chem. Phys., 10, 8899-8915, doi:10.5194/acp-10-8899-2010, 2010.

Mason, B.: Principles of Geochemistry, 3rd ed. ed., John Wiley, New York, USA, 329 pp., 1966.

Matsuki, A., Quennehen, B., Schwarzenboeck, A., Crumeyrolle, S., Venzac, H., Laj, P., and Gomes, L.: Temporal and vertical variations of aerosol physical and chemical properties over West Africa: AMMA aircraft campaign in summer 2006, Atmos. Chem. Phys., 10, 8437-8451, doi:10.5194/acp-10-84372010, 2010.

McConnell, C. L., Highwood, E. J., Coe, H., Formenti, P., Anderson, B., Osborne, S., Nava, S., Desboeufs, K., Chen, G., and Harrison, M. A. J.: Seasonal variations of the physical and optical characteristics of Saharan dust: Results from the Dust Outflow and Deposition to the Ocean (DODO) experiment, J. Geophys. Res., 113, D14S05, doi:10.1029/2007jd009606, 2008.

McConnell, C. L., Formenti, P., Highwood, E. J., and Harrison, M. A. J.: Using aircraft measurements to determine the refractive index of Saharan dust during the DODO Experiments, Atmos. Chem. Phys., 10, 3081-3098, doi:10.5194/acp-10-3081-2010, 2010.

Mehra, O. P., and Jackson, M. L.: Iron oxide removal from soils and clays by a dithionite-citrate buffered with sodium bicarbonate, Clay Minerals, 7, 317-327, 1960.

Minga, A., Thouret, V., Saunois, M., Delon, C., Serça, D., Mari, C., Sauvage, B., Mariscal, A., Leriche, M., and Cros, B.: What caused extreme ozone concentrations over Cotonou in December 2005?, Atmos. Chem. Phys., 10, 895-907, doi:10.5194/acp-10895-2010, 2010.

Moreno, T., Querol, X., Castillo, S., Alastuey, A., Cuevas, E., Herrmann, L., Mounkaila, M., Elvira, J., and Gibbons, W.: Geochemical variations in aeolian mineral particles from the SaharaSahel Dust Corridor, Chemosphere, 65, 261-270, 2006.

Mounkaila, M.: Spectral and mineralogical properties of potential dust sources on a transect from the Bodélé depression (Central Sahara) to the Lake Chad in the Sahel, Hohenheimer Bodenkundliche Hefte, 78, 1-311, 2006.

Müller, T., Schladitz, A., Massling, A., Kaaden, N., Kandler, K., and Wiedensohler, A.: Spectral absorption coefficients and imaginary parts of refractive indices of Saharan dust during SAMUM1, Tellus B, 61, 79-95, doi:10.1111/j.1600-0889.2008.00399.x, 2009.

N'Tchayi, G. M., Bertrand, J., Legrand, M., and Baudet, J.: Temporal and spatial variations of the atmospheric dust loading throughout West Africa over the last thirty years, Ann. Geophys., 12, 265-273, doi:10.1007/s00585-994-0265-3, 1994.

N'Tchayi Mbourou, G., Bertrand, J., and Nicholson, S. E.: The diurnal and seasonal cycles of wind-borne dust over Africa north of the equator, J. Appl. Meteor., 36, 868-882, 1997.

Osborne, S. R., Johnson, B. T., Haywood, J. M., Baran, A. J., Harrison, M. A. J., and McConnell, C. L.: Physical and optical properties of mineral dust aerosol during the Dust and Biomass-burning Experiment, J. Geophys. Res., 113, D00C03, doi:10.1029/2007jd009551, 2008.

Otto, S., de Reus, M., Trautmann, T., Thomas, A., Wendisch, M., and Borrmann, S.: Atmospheric radiative effects of an in situ measured Saharan dust plume and the role of large particles, At- mos. Chem. Phys., 7, 4887-4903, doi:10.5194/acp-7-4887-2007, 2007.

Petzold, A., Rasp, K., Weinzierl, B., Esselborn, M., Hamburger, T., Dörnbrack, A., Kandler, K., Schütz, L., Knippertz, P., Fiebig, M., and Virkkula, A.: Saharan dust absorption and refractive index from aircraft-based observations during SAMUM 2006, Tellus B, 61, 118-130, doi:10.1111/j.1600-0889.2008.00383.x, 2009.

Prospero, J.: Long-term measurements of the transport of African mineral dust to the southeastern United States: Implications for regional air quality, J. Geophys. Res., 104, 15917-15928, 1999.

Prospero, J. M. and Carlson, T. N.: Vertical and areal distribution of Saharan dust over the western equatorial north Atlantic Ocean., J. Geophys. Res., 77, 5255-5265, 1972.

Prospero, J., Glaccum, R., and Nees, R.: Atmospheric transport of soil dust from Africa to South America, Nature, 289, 570-572, 1981.

Prospero, J. M., Ginoux, P., Torres, O., Nicholson, S. E., and Gill, T. E.: Environmental characterization of global sources of atmospheric soil dust identified with the Nimbus 7 Total Ozone Mapping Spectrometer (TOMS) absorbing aerosol product., Rev. Geophys., 40, 2-1 to 2-31, 2002.

Pye, K.: Aeolian Dust and Dust Deposits., Academic Press, London, UK, 334 pp., 1987.

Rajot, J. L., Formenti, P., Alfaro, S., Desboeufs, K., Chevaillier, S., Chatenet, B., Gaudichet, A., Journet, E., Marticorena, B., Triquet, S., Maman, A., Mouget, N., and Zakou, A.: AMMA dust experiment: An overview of measurements performed during the dry season special observation period (SOP0) at the Banizoumbou (Niger) supersite, J. Geophys. Res., 113, D00C14, doi:10.1029/2008jd009906, 2008.

Redelsperger, J.-L., Thorncroft, C. D., Diedhiou, A., Lebel, T., Parker, D. J., and Polcher, J.: African Monsoon Multidisciplinary Analysis: An International Research Project and Field Campaign, B. Ame. Meteorol. Soc., 87, 1739-1746, doi:10.1175/BAMS-87-12-1739, 2006.

Redmond, H. E., Dial, K. D., and Thompson, J. E.: Light scattering and absorption by wind blown dust: Theory, measurement, and recent data, Aeolian Res., 2, 5-26, 2010.

Reeves, C. E., Formenti, P., Afif, C., Ancellet, G., Attié, J. L., Bechara, J., Borbon, A., Cairo, F., Coe, H., Crumeyrolle, S., Fierli, F., Flamant, C., Gomes, L., Hamburger, T., Jambert, C., Law, K. S., Mari, C., Jones, R. L., Matsuki, A., Mead, M. I., Methven, J., Mills, G. P., Minikin, A., Murphy, J. G., Nielsen, J. K., Oram, D. E., Parker, D. J., Richter, A., Schlager, H., Schwarzenboeck, A., and Thouret, V.: Chemical and aerosol characterisation of the troposphere over West Africa during the monsoon period as part of AMMA, Atmos. Chem. Phys., 10, 7575-7601, doi:10.5194/acp-10-7575-2010, 2010.

Reid, E. A., Reid, J. S., Meier, M. M., Dunlap, M. R., Cliff, S. S., Broumas, A., Perry, K., and Maring, H.: Characterization of African dust transported to Puerto Rico by individual particle and size segregated bulk analysis, J. Geophys. Res., 108, 8591, doi:10.1029/2002jd002935, 2003.

Reid, J. S., Westphal, D. L., Livingston, J. M., Savoie, D. L., Maring, H. B., Jonsson, H. H., Eleuterio, D. P., Kinney, J. E., and Reid, E. A.: Dust vertical distribution in the Caribbean during the Puerto Rico Dust Experiment, Geophys. Res. Lett., 29, 1151, doi:10.1029/2001g1014092, 2002.

Reid, J. S., Reid, E. A., Walker, A., Piketh, S., Cliff, S., Al 
Mandoos, A., Tsay, S.-C., and Eck, T. F.: Dynamics of southwest Asian dust particle size characteristics with implications for global dust research, J. Geophys. Res., 113, D14212, doi:10.1029/2007jd009752, 2008.

Saïd, F., Canut, G., Durand, P., Lohou, F., and Lothon, M.: Seasonal evolution of boundary-layer turbulence measured by aircraft during the AMMA 2006 Special Observation Period, Q. J. Roy. Meteorol. Soc. 136, 47-65, 2010.

Schladitz, A., Müller, T., Kaaden, N., Massling, A., Kandler, K., Ebert, M., Weinbruch, S., Deutscher, C., and Wiedensohler, A.: In situ measurements of optical properties at Tinfou (Morocco) during the Saharan Mineral Dust Experiment SAMUM 2006, Tellus B, 61, 64-78, doi:10.1111/j.1600-0889.2008.00397.x, 2009.

Schmel, G. A.: Deposition and resuspension, in: Atmospheric Science and Power Production, edited by: Randerson, D., 533-583, 1984.

Sokolik, I. and Toon, O.: Incorporation of mineralogical composition into models of the radiative properties of mineral aerosol from UV to IR wavelengths, J. Geophys. Res., 104, 9423-9444, 1999.

Sokolik, I. N., Winker, D. M., Bergametti, G., Gillette, D. A., Carmichael, G., Kaufman, Y. J., Gomes, L., Schuetz, L., and Penner, J. E.: Introduction to special section: Outstanding problems in quantifying the radiative impacts of mineral dust, J. Geophys. Res., 106, 18015-18027, doi:10.1029/2000jd900498, 2001.

Sow, M., Alfaro, S. C., Rajot, J. L., and Marticorena, B.: Size resolved dust emission fluxes measured in Niger during 3 dust storms of the AMMA experiment, Atmos. Chem. Phys., 9, 38813891, doi:10.5194/acp-9-3881-2009, 2009.

Spaan, W. P. and van den Abeele, G. D.: Wind born particle measurements with acoustic sensors, Soil Technol., 4, 51-63, 1991.

Taylor, S. R. and McLennan, S. M.: The continental crust: Its composition and evolution, Blackwell, Cambridge, Mass., USA, 312 pp., 1985.
Tegen, I. and Fung, I.: Modeling of mineral dust in the atmosphere: Sources, transport, and optical thickness, J. Geophys. Res., 99, 22897-22914, 1994.

Tesche, M., Ansmann, A., Müller, D., Althausen, D., Mattis, I., Heese, B., Freudenthaler, V., Wiegner, M., Esselborn, M., Pisani, G., and Knippertz, P.: Vertical profiling of Saharan dust with Raman lidars and airborne HSRL in southern Morocco during SAMUM, Tellus B, 61, 144-164, doi:10.1111/j.16000889.2008.00390.x, 2009.

Thouret, V., Saunois, M., Minga, A., Mariscal, A., Sauvage, B., Solete, A., Agbangla, D., Nédélec, P., Mari, C., Reeves, C. E., and Schlager, H.: An overview of two years of ozone radio soundings over Cotonou as part of AMMA, Atmos. Chem. Phys., 9, 6157-6174, doi:10.5194/acp-9-6157-2009, 2009.

Todd, M. C., Bou Karam, D., Cavazos, C., Bouet, C., Heinold, B., Baldasano, J. M., Cautenet, G., Koren, I., Perez, C., Solmon, F., Tegen, I., Tulet, P., Washington, R., and Zakey, A.: Quantifying uncertainty in estimates of mineral dust flux: An intercomparison of model performance over the Bodélé Depression, northern Chad, J. Geophys. Res., 113, D24107, doi:10.1029/2008jd010476, 2008.

Weinzierl, B., Petzold, A., Esselborn, M., Wirth, M., Rasp, K., Kandler, K., Schütz, L., Koepke, P., and Fiebig, M.: Airborne measurements of dust layer properties, particle size distribution and mixing state of Saharan dust during SAMUM 2006, Tellus B, 61, 96-117, doi:10.1111/j.1600-0889.2008.00392.x, 2009.

Weingartner, E., Saathoff, H., Schnaiter, M., Streit, N., Bitnar, B., and Baltensperger, U.: Absorption of light by soot particles: determination of the absorption coefficient by means of aethalometers, J. Aerosol Sci., 34, 1445-1463, 2003.

Yoshioka, M., Mahowald, N., Dufresne, J.-L., and Luo, C.: Simulation of absorbing aerosol indices for African dust, J. Geophys. Res., 110, D18S17, doi:10.1029/2004jd005276, 2005. 